\title{
Siyasal Pazarlama Sürecinde Sosyal Medya ve Elektronik Ağıdan Ağıza iletişime Yönelik Yapısal Bir Model Önerisi ${ }^{1}$
}

\author{
Ali Tehci \\ Salih Yıldız ${ }^{3}$
}

Siyasal Pazarlama Sürecinde Sosyal Medya ve Elektronik Ağızdan Ağıza İletişime Yönelik Yapısal Bir Model Önerisi

Öz

Bu çalışmanın amacı siyasal pazarlama sosyal medya faktörünün seçmen davranışı ile ilişkisinde güven, sadakat ve elektronik ağızdan ağıza iletişimin yapısal bir model aracılığı ile incelenmesidir. Araştırma verileri sosyal medya kullanıcısı 540 kişiye uygulanan elektronik anket neticesinde elde edilmiştir. İstatistik paket programlarında veriler analiz edilmiş, hipotezler yapısal eşitlik modeli ile test edilmiştir. Araştırma neticesinde siyasal pazarlama sosyal medya faktörünün seçmen güveni, sadakati ve elektronik ağızdan ağıza iletişime, bu faktörlerin ise seçmen davranışına etki ettiği sonucuna ulaşılmıştır.

Anahtar Kelimeler: Siyasal Pazarlama, Sosyal Medya, Elektronik Ağızdan Ağıza İletişim, Seçmen Güveni, Seçmen Sadakati, Seçmen Davranışı.

\section{Proposal of a Structural Model about Social Media and} Electronic Word of Mouth Communication in Political Marketing Process

\begin{abstract}
The purpose of this study is to investigate trust, loyalty and electronic word of mouth communication in relation to political marketing social media factor on voter behavior through a structural model. The survey data was obtained on the basis of the electronic questionnaire applied to 540 social media users. The data was analyzed in statistical package programs, the hypotheses were tested with structural equation model. As a result of the research, it has been reached that the political marketing social media factor affect to voter trust, loyalty and electronic word of mouth communication and these factors affect voter behavior.
\end{abstract}

Keywords: Political Marketing, Social Media, Electronic Word of Mouth Communication, Voter Trust, Voter Loyalty, Voter Behavior.

\section{Giriş}

Pazarlama insan hayatı içerisinde sürekli yer alan, teknolojik gelişmelere paralel olarak kendini güncelleyen ve özellikle modern toplumun ayrılmaz bir parçası haline gelen önemli bir faaliyettir. Pazarlama ticari ürünlerin satılmasının ötesine geçen yaygın bir toplumsal etkinlik olarak ifade edilmektedir (Kotler ve Levy, 1969: 10). Pazarlama kavramının genişlemesi fikirlerin, kurumların ve kişilerin pazarlanması durumu siyasal pazarlama yöntem ve süreçlerini gündeme getirmiştir. Literatürde politik pazarlama olarak da kullanılan siyasal pazarlama siyaset, pazarlama, iletişim ve seçmen davranışlarını kapsayan bir süreç olarak değerlendirilebilmektedir. Siyaset bilimi ise ilkeler, ideolojiler ve siyasi anlamda fikirler ile ilgilenmektedir (Lees-Marshment, 2014: 11). Siyasal pazarlama siyaset ve pazarlama biliminin evliliği olarak ifade edilmiştir (LeesMarshment, 2001: 692). Siyaset bilimcilerin siyasal pazarlamayı sadece seçim öncesi dönemde siyasal iletişim olarak algıladıkları ifade edilmektedir (Lock ve Harris 1996: 20). Fakat siyasal iletişim, siyasal pazarlama ve siyaset biliminin ortak çalışma alanı olarak görülmektedir (LeesMarshment, 2003: 14; Temple, 2010: 275). Başlangıçta propaganda kavramı ile eş tutulan siyasal pazarlama (Tan ve Baydaş, 2017: 601) sadece pazarlama uygulamaları ile sınırlı kalmayan,

\footnotetext{
${ }^{1}$ Bu çalışma Gümüşhane Üniversitesi Sosyal Bilimler Enstitüsü İ̧letme Anabilim Dalında Doç. Dr. Salih Yıldız danışmanIığında Ali Tehci tarafından "Siyasal Pazarlama Sürecinde Sosyal Medya ve Elektronik Ağızdan Ağıza iletişim" ismiyle tamamlanarak 17.12.2018 tarihinde savunulan doktora tezinden türetilmiştir.

${ }^{2}$ Dr., Ordu Üniversitesi. a.tehci@odu.edu.tr, Yazar ORCID bilgisi: http://orcid.org/0000-0001-9949-2794

${ }^{3}$ Doç. Dr., Gümüşhane Üniversitesi IiBF, İşletme Bölümü. salihyildiz@gumushane.edu.tr, Yazar ORCID bilgisi: http://orcid.org/ 0000-0002-1002-5960
} 
tüm siyasal alışverişleri de kapsamayan (Hennenberg, 2008: 158) ve bilginin akıllı bir şekilde işlenişine kadar kullanılan pazarlama faaliyetidir (Vidagdo vd., 2014: 47).

Siyasal pazarlama teriminin ilk olarak Kelley (1956) tarafından kullanıldığı belirtilmektedir (Wring, 1997: 2; Bayraktaroğlu, 2002: 160). Amerikan Pazarlama Derneği 1985 yılında "fikirler" kelimesini de dâhil ederek pazarlamayı yeniden tanımlamış ve siyasal pazarlama kavramını benimsemiştir (Scammel, 1999: 725; Kolovas ve Harris, 2005: 4). Bu anlamda "fikir", politik aktörler ile pazarlamacılar ve seçmen olarak tüketiciler arasındaki değişim nesnesidir. Gronroos (1990) toplum ve siyasi partilere yönelik olarak siyasal pazarlamayı, hedeflere ulaşmak için uzun dönemli seçmen ilişkilerinin sürdürülmesi ve geliştirilmesi olarak ifade etmiştir (MohamadNor vd., 2009: 1). Bongrad (1992) ise siyasal pazarlamayı oy verme hakkı, demokrasi ve bilgi araçlarındaki gelişmenin bir sonucu olarak gereksinim duyulan siyasal iletişimin en son araçlarından biri olarak görmektedir (Bongrand, 1992: 9). Amerikan Pazarlama Derneğinin pazarlama sözlügünde ise siyasal pazarlama belirli bir parti veya kişilerin oylarını artırmak için hedef kitleleri etkilemek adına tasarlanmış pazarlama uygulamaları olarak tanımlanmıştır (www.ama.org). Siyasal pazarlamanın örgütsel oluşumları pratikte aşarak seçmenler ile siyasi partiler veya adaylar arasındaki iletişim süreci (Shama, 1975; Lock ve Harris, 1996; Wring, 1997) olarak tanımlandığı belirtilmektedir (Baines vd., 2002: 6).

Geleneksel pazarlamada pazarlama faaliyetlerinin içeriğini ve temelini oluşturan pazarlama karması elemanlarının (Grönroos, 1994: 5), siyasal pazarlamaya uyarlanmasının siyasal hayatın gelişimine katkı sağlayacağı ve seçimleri etkileyebileceği ifade edilmektedir (Divanoğlu, 2008: 106; Maryani, 2015: 105). Dolayısıyla siyasal pazarlama seçmen ihtiyaçlarının tespiti ve karşılanması için siyasal ürünlerin geliştirilmesi, fiyatlandırılması, dağıtımı ve tutundurulması ile ilgili süreçler bütünü olarak da tanımlanabilmektedir (Polat ve Külter, 2008: 6). Siyasal pazarlama, siyaset biliminin ilgi alanlarından olan kamu yönetimi, siyasi partiler, medya, seçmen davranışı ve odak gruplar gibi alanlardan faydalanmaya çalışmaktadır (Lees-Marshment, 2003: 14). Bu bağlamda siyasal pazarlamayı, günümüz yoğun rekabet ortamında geleneksel ve modern pazarlama tekniklerini kullanarak belirli oy potansiyeline ulaşmayı, seçmen güven ve sadakatini sağlamayı amaçlayan seçmen odaklı bir pazarlama süreci olarak değerlendirmek mümkündür.

Siyasi partilerin ideolojik ve demografik bir tanımlama içerisinde bulunmak istemeleri farklı pazarlama stratejisi uygulamalarını zorunlu kılmaktadır (Okumuş, 2007: 160). Ölçümleme yapmak için çeşitli sosyal bilim araçlarından, ağırlıklı olarak odak gruplardan ve anketlerden yararlanan siyasal pazarlama (Lees-Marshment, 2003: 11) pazar araştırması, bölümlendirme, konumlandırma, markalaşma, pazarlama iletişimi ve yönetimi gibi araçlardan yararlanmaktadır (Marland vd., 2011: 8-9). Pazarlama hedeflerinin belirlenmesine ve bu hedeflerin gerçekleştirilmesine yönelik mantıksal bir dizi faaliyetler bütünü (McDonald, 1989: 19) olarak tanımlanan pazarlama planlaması, kar amacı olan veya olmayan bütün kurumlarda rekabet avantajının sağlanmasında oldukça önem arz etmektedir. Dünün stratejileri bugünün stratejileri için bazı yollar ve girdiler sağlayacak, bugünün stratejileri ise geleceği inşa edecektir (Pettigrew, 1977: 79). Dolayısıyla Nimmo (1999) seçimlere yönelik bilgi edinmek için siyasal pazarlamanın sadece kısa dönem taktiksel bir araç olarak değil, kalıcı olarak devam eden bir yöntem olarak ele alınması gerektiğini ifade etmiştir (Smith ve Hirst, 2001: 1058). Bu durum partilere kampanyalar, analizler, planlama ve uygulama yoluyla farklı seçmen kitlelerine hitap etme olanağı sunmakta (O'Cass, 1996: 40) ve yoğun rekabete dayalı siyasi alanlarda başarıyı da getirebilmektedir.

Siyasete değişimi ve birçok yeniliği getiren pazarlama bilimi ve internet olanakları neticesinde yeni medya siyasi hayatta önemli rol oynamakta (Kırkbir ve Cançelik, 2013: 59), siyasi 
partilere ve adaylara teknolojiyi kullanma konusunda fırsatlar sunmaktadır. Dijital iletişim teknolojilerinin artan kullanımı ile birlikte siyasal pazarlama sosyal ağlar gibi güncel araçları kullanarak seçmenlere ulaşmaya çalışmaktadır. Bu yöntemlerden biri olan ve seçmenlerle iletişim kurmak için oldukça fazla kullanılan sosyal medya siyasi partilere olumlu anlamda katkılar sunabilmektedir (Effing vd., 2011: 25). Kar amacı gütmeyen kuruluşlar da dahil olmak üzere bütün kesimin hedef kitleleri ile iletişim kurmasına olanak sağlayan sosyal medya kanalıyla elde edilen veriler ile seçmen davranışlarına ve seçimlere yönelik sonuçlara ulaşılabilmektedir (Digrazia vd., 2013: 2). Siyasal pazarlama sürecinde etkileşimli çevrimiçi araçları kullanmanın aday ve seçmen arasındaki ilişkiyi geliştirme, parti desteği sağlanmasına katkıda bulunma, bireyler veya fonları harekete geçirme gibi yararları bulunmaktadır (Lilleker vd., 2010: 107). Bu nedenle çift yönlü katılımın olduğu iletişim araçları olarak sosyal medya araçlarının siyasal konularda her geçen gün daha fazla kullanıldığı görülmektedir.

Siyasal pazarlama sürecinde ağızdan ağıza iletişim faktörü siyasi patilerin veya adayların ilgilenmesi gereken bir konudur. Siyasi adaylar medya aracılığı ile iletişime ve kampanyalara oldukça önem vermektedirler. Ancak seçmenler bir karar verirken çevrelerinden de bazı görüşler alabilmektedirler. Bu nedenle adayların seçmenlerle iletişim kurabilmeleri için ağızdan ağıza iletişim faktörü önemlidir (Argan ve Argan, 2012: 71). Marka, ürün veya hizmet hakkındaki bilgilerin kişiden kişiye aktarımı (Arndt, 1967: 292) olarak tanımlanan ağızdan ağıza iletişimin bilgi aktarımının en eski yolarından biri olduğu (Dellarocas, 2003: 1408) genellikle güven, memnuniyet ve sadakat ile ilgili faktörlerle ilişkili olduğu ifade edilmektedir (Ahrens vd., 2013: 1036). Ticari amaç gütmeksizin çevrimiçi bilgi değişimi olarak ifade edilen elektronik ağızdan ağıza iletişim (Çilingir vd.,, 2010: 96; Wu ve Wang, 2011: 448; Yıldız, 2016: 158) ise internet tabanlı uygulamalar ile yapılan ve resmi olmayan tüm kişiler arası iletişimi (Harrison-Walker, 2001: 63; Litvin vd., 2008: 461), bir ürün veya hizmet ile ilgili öneri, fikir veya deneyimlerin paylaşılmasını kapsamaktadır (Nadarajan vd., 2017: 388). Bireylerin sosyal medya ortamlarında bulunma süreleri her geçen gün artmakta, bir ürün veya hizmet hakkındaki deneyimleri, olumlu veya olumsuz fikirleri paylaşmaları konusunda da bu ortamlar bir araç olarak karşımıza çıkmaktadır. Cheung vd. (2008)'e göre sosyal ağlar ile pek çok birey çeşitli nedenlerle diğer bireylerin fikirlerinde değişikliğe neden olabilmektedir. Elektronik ağızdan ağıza iletişim ile bireylerin fikir ve deneyimlerini paylaşmalarına olanak sağlayan sosyal medya (Balakrishnan, 2014: 178) ağızdan ağıza iletişimin yapılacağı bir ortam olarak değerlendirilmektedir (Chu ve Kim, 2011: 48).

\section{Kuramsal Çerçeve}

\subsection{Seçmen Güveni}

Karmaşık ve çok boyutlu kavram olan güven faktörünün literatürde farklı şekillerde tanımlandığı görülmekte olup, bu anlamda sosyoloji, psikoloji, ekonomi ve pazarlama disiplinlerinde araştırmalar yapılmaktadır (Papadopoulou vd., 2001: 323). Tüketicilerle uzun dönemli ilişkilerin sürdürülmesinde oldukça önemli olan (Sharma ve Patterson 2000: 471) ve bir tarafın diğer tarafın güvenilirliğine inanması neticesinde oluşan durumun kavramsallaştırılması (Morgan ve Hunt, 1994: 23) olarak tanımlanan güven, değişim ortağına duyulan inanma isteği olarak tanımlanmaktadır (Moorman vd., 1992: 315). Rotter (1967)'ye göre güven, belirli bir değişim ilişkisinde bir tarafın diğerine sağladığı güvenilirlik seviyesidir (Nguyen vd., 2013: 99). Güven, alıcı ve satıcı ilişkisi içinde bulunan taraflardan birinin gereksinimlerini diğer tarafın gelecekte karşılayacağına dair davranışlar göstermesi ve gereksinim sahibinin onun bu davranışlarına inanması olarak tanımlanmıştır (Anderson ve Weitz, 1989: 312). 
Sosyal etkileşimlerde ve uzun süreli ilişkilerde önemli olan güven (Ahmed vd., 2011: 131), bir siyasi parti ve seçmenler de dahil olmak üzere birçok etkileşimin temelidir (Dabula, 2017: 81). Bu anlamda güven, siyasi liderler ve seçmenler arasındaki ilişkilerin güçlendirilmesinde temel bağlayıcı güç olarak ifade edilmektedir (Ahmed vd., 2011: 132). Seçmen güveni bir siyasi adayın veya partinin sözlerine ve vaatlerine itimat edilmesi durumu ile ilgili seçmenlerin beklentileri olarak tanımlanmıştır (Schiffman vd., 2010: 371). Geleneksel medyadan farklı olarak sosyal medya şeffaflık, etkileşim ve bilgi paylaşımı sağlayan çok yönlü bir araçtır. Sosyal medya platformlarının sunduğu ilişki imkânlarını değerlendiren ve koruyan pazarlamacıların, her geçen gün artan etkileşim hacminin ortasında tüketicilerin beklentilerini karşılarken bu etkileşim ile gerçekleşen ilişkilerin iyi anlaşılması gerekmektedir (Labrecque, 2014: 135). Hemen hemen her alanda olduğu gibi pazarlama alanında ve dolayısıyla da değişim süreçlerindeki ilişkilerin geliştirilmesinde, korunmasında güven oldukça önemli bir kavram olarak karşımıza çıkmaktadır. Bu nedenle çalışmada siyasal pazarlama sosyal medya faktörünün elektronik ağızdan ağıza iletişime ve seçmen davranışına etkisi araştırıırken, siyasal pazarlama sosyal medya faktörünün etkileşimlerde ve ilişkilerde önemli bir unsur olan güven faktörüne etkisi tespit edilmeye çalışımıştır.

\subsection{Seçmen Sadakati}

Müşteri sadakati tüketicilerin tercihlerinde değişiklik yaratacak pazarlama çabalarına rağmen, önceden tercih edilen ürün veya hizmetin tekrar satın alınması olarak ifade edilmektedir (Oliver, 1999: 43). Müşterilerin beklentilerini karşılamak, müşteri sadakatini oluşturacak önemli stratejilerden biridir. Hizmet sektöründe maliyetlerin azaltılması, rekabet üstünlüğünün ve karIılığın artııılmasında sadakat oldukça önemlidir (Çatı vd., 2010: 433). Sadık müşterilerin potansiyel müşterileri işletmeye yönlendirmesi muhtemeldir. Bu nedenle bir çok işletme müşteri sadakatini işetmenin temel hedeflerinden biri olarak görmektedir (Tsai vd., 2010: 732). Elektronik hizmet sektöründe de sadakatin önemli olduğu, müşterilerin sadık hale getirilmesi için müşterilerde güven ve tatmin oluşturulması gerektiği vurgulanmaktadır (Yıldız ve Çilingir, 2010: 424). Müşterilerin aldıkları hizmet karşılı̆ında kümülatif deneyimleri ile zaman içerisinde oluşan sadakatin (Kim vd. 2007: 823), aynı zamanda bir marka için olumlu tutumlar geliştiğinde ve tekrar satınalma davranışında ortaya çıktığı belirtilmektedir (Keller, 1993: 8). Literatürde güven ve sadakat arasında pozitif bir ilişki olduğu, müşteri sadakatinde güvenin rolünün önemli olduğu ifade edilmektedir (Sarwar, 2012: 28). Daha fazla sadakati olan bir müşterinin daha yüksek bir fiyat toleransına ve ürünü çevresindekilere tavsiyede bulunmaya daha istekli olacağı söylenmektedir (Srinivasan vd., 2002: 47).

Tüketicilerin, işletmelerin veya kuruluşların müşterileri olarak devam etme niyetlerini ifade eden sadakat (Jacoby ve Kryner 1973: 2), siyasal anlamda ise seçmenlerin tekrar aynı partiye oy vermesi ile açıklanmaktadır (Smith ve Spotswood, 2013: 12). Tüketici karar sürecinin önemli bir sonucu olan sadakat seçmen karar sürecinin de önemli bir sonucu olarak görülmektedir. Bu anlamda seçmen sadakati için iki ayrı seçime atıfta bulunulmakta, seçmenlerin iki ayrı seçimde de aynı siyasi partiyi veya adayı tercih ettiklerinde sadık oldukları ifade edilmektedir (Chiru ve Gherghina, 2012: 31). Modern toplumlarda partinin başarısı ve seçim öncesi vaatlerine sadakati seçmenin de sadakatini sağlamakta, aksi durumda ise seçmenin olumsuz sonuçlar neticesinde partiden koparak farklı partilere yönelmesi gerçekleşebilmektedir (Bayrakdaroğlu vd., 2016: 917). Gerek ticari gerekse siyasi alanda müşteri ilişkileri odaklı faaliyetler, sadık müşterileri (seçmenleri) oluşturmaya yardımcı olabilmektedir. Sosyal medyada bu anlamda bir işletme veya siyasi parti için değerli bir araç olarak görülmektedir (Dabula, 2017: 85). 


\subsection{Seçmen Davranışı}

Siyaset biliminin araştırdığı konulardan birisi olan oy verme davranışı, bir tüketim kararı olması nedeniyle pazarlamacıların da ilgisini çeken bir konu haline gelmiştir. Seçmenlerin oy verme kararı olan bu tüketim kararında partinin gündemi gibi bir faktörden, liderin yaşantısı gibi özel bir faktöre kadar bir çok durum etkili olabilmektedir (Bayrakdaroğlu vd., 2016: 908). Seçmenlerin her zaman rasyonel davranmadıkları, ideoloji, aile, referans grupları, seçim kampanyaları ve algılanan hizmet kalitesi gibi faktörlerin etkisiyle de oy verme davranışında bulunabildikleri ifade edilmektedir (Usta ve Memiş, 2009: 218). Seçmen davranışını etkileyen faktörler ülkeden ülkeye de değişebilmektedir (Tan ve Baydaş, 595). Dolayısıyla demokratik sistemin etkin bir şekilde sürdürülmesini sağlayan seçmen davranışları ile ilgili bir birini tamamlayıcı nitelikte geliştirilen bilimsel yaklaşımlar (Yıldırım, 2014: 16), demokratik sistemlerin gelişmeye başlaması ile birlikte seçmenlerin oy verme davranışları siyasal pazarlamacıların da ilgisini çekmeye başlamıştır (Falkowski ve Cwalina, 2002: 138).

Pazar odaklıık, ürün geliştirme, hedefleme, etkin rekabet, pazar odaklı siyasal iletişim, dijital pazarlama ve pazar analizleri siyasal pazarlamanın ilkeleri arasındadır (Lees-Marhsment, 2009: 458). Seçmenlerin önceki seçimlere göre parti tercihlerindeki değişiklikler, seçmenlerin düşüncelerinin belirlenmesi, oyların seviyeleri ve partiye olan desteğin seviyesi gibi konuların analiz edilmesi gerekmektedir (Baines vd., 2002: 10). Özellikle batı ülkelerinde seçim süreçlerinin analiz edilmesi ile ilgili araştırmaların 1940'lı yıllardan sonra gelişme gösterdiği söylenebilmektedir. Bu anlamda seçmen davranışlarına yönelik yapılan bilimsel çalışmaların sosyolojik, sosyo-psikolojik ve ekonomik olmak üzere üç başlık altında incelendiği görülmektedir (Harrop ve Miller, 1987: 130; Gökçe vd., 2002: 7; Falkowski ve Cwalina, 2002: 138).

Sosyolojik seçmen davranışı yaklaşımında toplumsal etkilerin önemi (Visser, 1998: 25) nedeniyle bireylerin tutum ve davranışlarında çevresindeki kişilerden etkileneceği varsayılmaktadır (Gökçe vd., 2002: 7; Çavuşoğlu ve Pekkaya, 2016: 21). Dolayısıyla dinsel, etnik ve mesleki durumların sosyal bölünmeler nedeniyle seçmen tercihlerinde önemli etki oluşturduğu (Çinko, 2006: 109; Başarır, 2016: 220), siyasal davranışları etkileyen tüm faktörlerin siyaseti ve siyasi tercihleri de etkilediği ifade edilmektedir (Beren, 2013: 194). Sosyo-psikolojik yaklaşımda bireylerin küçük yaşlardan itibaren aile ve çevreden etkilenerek bir partiye yakınlık duymaya başladığı ve bu bağlılığın güçlenerek devam ettiği varsayılmaktadır (Gökçe vd., 2002: 9). Rasyonel seçim yaklaşımı olarak da bilinen ekonomik oy verme yaklaşımına göre ise seçmenler çıkarlarını bilerek seçimlerde kendi çıkarlarına uygun gördükleri partiye veya adaya oy vermektedirler (Gökçe vd., 2002: 9; Çavuşoğlu ve Pekkaya, 2016: 21). Yine bu yaklaşıma göre her zaman kendi çıkarları doğrultusunda karar veren insanlarda parti bağımlılı̆ı bulunmamakla birlikte ülkeyi kim daha iyi yönetecekse ona oy veririm düşüncesi hâkim olmaktadır. Özellikle son yıllarda bu düşüncede önemli bir kitle olduğunun gözlemlendiği belirtilmektedir (Barış, 2009: 74; Başarır, 2016: 221). Ekonomik değişkenleri dikkate alan bu yaklaşımda seçmenlerin tek amacının maddi çıkar olduğu, seçmenin belirli amacını eğer parti gerçekleştirmede yetersiz kalırsa seçmenin bir sonraki seçimde kolayca taraf değiştirebileceği belirtilmektedir (Gökçe vd., 2002: 9; Akgün, 2007: 30; Yıldırım, 2014: 16).

Araştırma metotlarının gelişmesi, yeni teorilerin ortaya çıkışı ile birlikte bu yaklaşımlar sürekli olarak gelişmekte, bu anlamda bir takım değişiklikler ve takviyeler ortaya çıkmaktadır. Toplumların politik kültürü ve yaşamındaki değişimler nedeniyle bu yaklaşımların seçmen davranışlarını tahmin etmek için yeterli olmadığı da ileri sürülmektedir (Dalton ve Wattenberg, 
1993; Riley, 1988; Falkowski ve Cwalina, 2002: 138). Sonuç olarak bütün çalışmalar seçmen davranışlarının analizi için teorik çerçevede yararlı olabilmektedir (Schofiled ve Reeves, 2015: 970).

\section{Araştırmanın Amacı, Modeli ve Hipotezleri}

Gerek siyasal pazarlama gerekse sosyal medya üzerine birçok çalışmanın literatüre kazandırıldığı görülmektedir. Bu çalışmada siyasal pazarlama, sosyal medya ve elektronik ağızdan ağıza iletişim olmak üzere üç kavramsal yapı birlikte değerlendirilmiştir. Bu bağlamda çalışmanın amacı siyasal pazarlama sosyal medya faktörünün seçmen güveni ve sadakati üzerindeki etkileri ile seçmen güveni, sadakatinin elektronik ağızdan ağıza iletişime ve seçmen davranışına etkilerinin yapısal olarak incelenmesidir. Araştırma modeli Kushin ve Yamamoto (2010), Yang ve DeHart (2016), Dabula (2017) çalışmaları ile literatüre katmış oldukları model geliştirilerek oluşturulmuştur. Aynı zamanda gerekli literatür çalışması yapılarak modele elektronik ağızdan ağıza iletişim faktörü de dahil edilmiştir. Araştırmanın amacı doğrultusunda oluşturulan yapısal model Şekil 1'de gösterilmektedir.

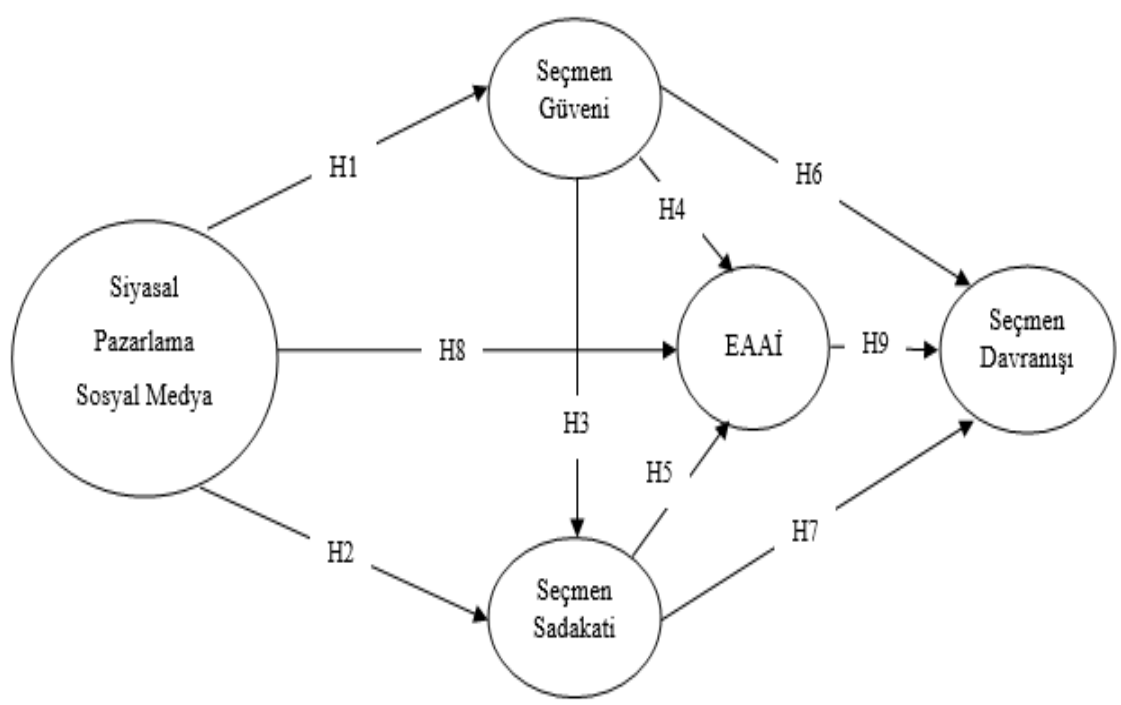

Şekil 1: Araştırmanın Modeli

Gillmor (2004) insanların geleneksel medyada olumsuz fikirlerle karşılaşabileceklerini belirtirken, sosyal medyanın öncelikle içeriğinin kullanıcılar tarafından oluşturulmasının onların ilgilerini, siyasi partilere ve liderlere olan güvenlerini artıracağını ifade etmiştir. Valenzuela vd., (2009) Facebook kullanım yoğunluğunun sosyal güven ile pozitif ilişkili olduğunu belirtmişlerdir. Riezebos vd., (2011 sosyal medya ve siyasal güven faktörü ile siyasal parti algısı arasında ilişki olduğunu tespit etmişlerdir. Bilginin çok daha hızlı ve düşük maliyetle iletilmesine imkân sağlayan sosyal medyanın güven üzerinde olumlu bir etkisinin olduğu söylenebilmektedir (Hakansson ve Witmer, 2015: 518). Mehrabi vd. (2014) çalışmalarında sosyal medya pazarlaması ile müşterilerin marka sadakati arasında pozitif bir ilişki olduğunu, Huang vd. (2018) ise sosyal medyanın marka sadakati üzerinde doğrudan etkisi olduğunu tespit etmişlerdir. Nevzat vd. (2016) Facebook topluluğunun algılanan gücünün, üniversite toplumu ve üniversite markasıyla özdeşleşmesiyle ilişkili olduğunu ve bunun da güven ve sadakat ile ilgili olduğunu, üniversitelerin güven ve sadakatin gelişmesinde sosyal medya kullanımından yararlanabileceğini belirtmişlerdir. Dabula (2017) ise siyasal pazarlamada sosyal medyanın kullanılması ile seçmen güveni ve 
sadakati arasında pozitif bir ilişki olduğunu tespit etmiştir. Bu bağlamda pazarlama literatüründe önemli olan güven ve sadakat çalışmaya dâhil edilmiş ve aşağıdaki hipotezler belirlenmiştir.

H1: Siyasal pazarlama sosyal medya faktörünün seçmen güveni üzerinde doğrudan etkisi vardır.

H2: Siyasal pazarlama sosyal medya faktörünün seçmen sadakati üzerinde doğrudan ve dolaylı etkisi vardır.

Genel olarak değerlendirildiğinde literatürde elektronik ağızdan ağıza iletişim ve güven ile elektronik ağızdan ağıza iletişim ve sadakat arasındaki ilişkiyi inceleyen çalışmalara rastlamak mümkündür. Horppu vd. (2008) web sitesi düzeyinde memnuniyet ve güvenin web sitesi sadakatinin belirleyicileri olduğunu tespit etmiştir. Son vd. (2012) çalışmasında memnuniyet ve sadakatin elektronik ağızdan ağıza iletişimi etkileyen bir faktör olarak öneminden bahsetmiştir. Joorhari (2015) çevrimiçi mağazalarda elektronik ağızdan ağıza iletişim, güven ve satın alma davranışı arasında pozitif ilişkiler olduğunu tespit etmişlerdir. Bozbay vd. (2017) ise elektronik güven, elektronik bağıılık ve elektronik ağızdan ağıza iletişim arasında anlamlı ilişkiler olduğunu tespit etmiştir. Dabula (2017) seçmen güveni ve seçmen sadakati arasında pozitif ilişki olduğunu tespit etmiştir. Bu kapsamda seçmen güveni, seçmen sadakati ve elektronik ağızdan ağıza iletişim ile ilgili aşağıdaki hipotezler belirlenmiştir.

H3: Seçmen güveninin seçmen sadakati üzerinde doğrudan etkisi vardır.

H4: Seçmen güveninin elektronik ağızdan ağıza iletişim üzerinde doğrudan ve dolaylı etkisi vardir.

H5: Seçmen sadakatinin elektronik ağızdan ağıza iletişim üzerinde doğrudan etkisi vardır.

Literatürde güvenin, sadakatin en önemli öncülerinden biri olduğunu ve sadakat üzerinde doğrudan, olumlu ve önemli bir etkiye sahip olduğunu belirten birçok çalışma bulunmakla birlikte, siyasal anlamda sadakat ve davranış arasındaki ilişkiyi araştıran çok fazla çalışmaya rastlanılmamaktadır. Chiru ve Gherghina (2012) ve Rachmat (2014) sadakat ve seçmen davranışı arasında bir ilişki olduğunu, seçmenlerin aynı siyasi partiye farklı zamanlarda oy verdiklerinde sadık olduklarını ifade etmişlerdir. İnsanların, seçim öncesi vaatlerin ve sorumlulukların yerine getirilip getirilmediğine ilişkin değerlendirmeleri ile seçmen güveninin geliştiği belirtilmektedir (Walsh vd. 2008; Agyapong 2011; Dabula 2017). Gefen (2000)'e göre güven, kararın ana itici gücüdür ve bu nedenle davranışa neden olmaktadır. Rachmat (2014)'e göre ise beklentilerin karşılanması neticesinde seçmenlerin oy verme davranışlarının ve kararlılıklarının güçleneceği varsayılmaktadır. Güven, seçmenlerle uzun süreli ilişkilerin geliştirilmesinde önemli bir rol oynamaktadır. Çeşitli araştırmalar, siyasal güven ve seçmen katılımı arasında pozitif bir ilişkinin olduğunu tespit etmişler ve siyasal güvenin oy verme davranışında çok güçlü bir etkisinin olduğunu belirtmişlerdir (Ahmed vd. 2011; Hooghe vd. 2011; Dabula 2017). Rachmat (2014) seçmen davranışları üzerinde siyasal marka güvenin etkisini tespit etmeye yönelik yapmış olduğu çalışmasında, aday marka güveninin seçmen davranışı üzerinde pozitif etkiye sahip olduğunu, ayrıca marka adayın dürüstlüğünün güven üzerinde önemli rol oynadığını belirtmiştir. Dabula (2017) ise seçmen güveni ve sadakati ile seçmen davranışı arasında pozitif bir ilişki olduğunu tespit etmiştir. Araştırma kapsamında seçmen güveni, sadakati ve seçmen davranışı ile ilgili aşağıdaki hipotezler belirlenmiştir.

H6: Seçmen güveninin seçmen davranışı üzerinde doğrudan ve dolaylı etkisi vardır.

H7: Seçmen sadakatinin seçmen davranışı üzerinde doğrudan ve dolaylı etkisi vardır. 
Literatürde elektronik ağızdan ağıza iletişimin tüketici davranışı üzerindeki etkisinin araştırıldığı çalışmalara rastlamak mümkündür. Dursunoğlu (2017) sosyal medyanın siyasal davranışın şekillenmesinde önemli bir faktör olduğunu belirtmiştir. Hodza vd. (2012) sosyal ağ siteleri aracılığıyla yapılan elektronik ağızdan ağıza iletişimin, tüketicilerin ürün algıları ve satın alma niyetleri üzerinde doğrudan olumlu bir etkiye sahip olduğunu ifade etmişlerdir. Sa'ait vd. (2016) ise elektronik ağızdan ağıza iletişimin bilgi paylaşımı neticesinde tüketici satın alma davranışı üzerinde etkili olduğunu tespit etmişlerdir. Saleem ve Ellahi (2017) sosyal ağlar üzerinden moda markalarının satın alınmasında elektronik ağızdan ağıza iletişimin etkili bir faktör olduğu sonucuna ulaşmışlardır. Öztürk ve Çoban (2019) ise siyasal pazarlama faaliyetlerinin ve ağızdan ağıza iletişimin seçmen davranışını olumlu yönde etkilediğini, ayrıca seçmen davranışları üzerinde siyasal pazarlama aktivitelerinin etkisine ağızdan ağıza iletişimin aracılık ettiğini tespit etmişlerdir. Bu bağlamda siyasal pazarlamada sosyal medya, elektronik ağızdan ağıza iletişim ve seçmen davranışı ile ilgili aşağıdaki hipotezler belirlenmiştir.

H8: Siyasal pazarlama sosyal medya faktörünün elektronik ağızdan ağıza iletişim üzerinde doğrudan ve dolaylı etkisi vardır.

H9: Elektronik ağızdan ağıza iletişim faktörünün seçmen davranışı üzerinde doğrudan etkisi vardir.

\section{Araştırmanın Kapsamı ve Kısıtları}

Araştırmanın evrenini Türkiye'de sosyal medya kullanıcısı 18 yaş üstü tüm bireyler oluşturmaktadır. Ancak araştırmada tüm bireylere ulaşmanın mümkün olmaması nedeniyle kolayda örnekleme yöntemi tercih edilmiştir. Örneklemin ana kütleyi iyi temsil etmesi açısından Facebook, Twitter gibi sosyal paylaşım siteleri aracılı̆̆ı ile mümkün olduğunca farklı sosyo-kültürel ve sosyoekonomik özellikteki bireylere ulaşılmaya çalışımıştır. Bu bağlamda istatistiki olarak araştırma evreninde yer alan kişi sayısına göre 0,05 güven düzeyinde 384 kişilik örneklem büyüklügü araştırmanın geneli kapsaması bakımından yeterli olsa da, bu araştırmanın sonuçlarının ankete katılan kişiler olduğu ve genellenmemesi gerektiği düşünülmektedir. Araştırma kapsamında sosyal medya kullanıcılarına yönelik olarak hazırlanan anket formu elektronik ortamda 20. 02. 2018 - 02.04.2018 tarihleri arasında 552 kişiye uygulanmış ve hatalı olduğu anlaşılan 12 anketin çıkarılması neticesinde 540 anket analize dâhil edilmiştir. Araştırmada Beşli Likert Ölçeği ile oluşturulan anket formunda ilk bölüm siyasal pazarlama sosyal medya, seçmen güveni, seçmen sadakati, elektronik ağızdan ağıza iletişim ve seçmen davranışı faktörlerini kapsamaktadır. Araştırma ölçekleri oluşturulurken Linan ve Chen (2009), Kushin ve Yamamoto (2010), Ayankoya (2014), Thoumrungroje (2014) ve Dabula (2017) çalışmalarından yararlanılmıştır. Araştırmanın ikinci bölümündeki sorular ise ankete katılan sosyal medya kullanıcılarının demografik özelliklerini belirlemeye yöneliktir. Katılımcıların demografik özellikleri Tablo 1'de gösterilmektedir. 
Tablo 1: Katılımcıların Demografik Özelliklerine Ilişkin Frekans ve Yüzdelik Dağılımları

\begin{tabular}{|c|c|c|c|c|c|}
\hline Eğitim & $\mathbf{N}$ & $\%$ & Yaş & $\mathbf{N}$ & $\%$ \\
\hline İlköğretim & 45 & 8,3 & $18-28$ & 280 & 51,9 \\
\hline Lise & 107 & 19,8 & $29-39$ & 160 & 29,6 \\
\hline Üniversitesi & 303 & 56,1 & $40-50$ & 64 & 11,9 \\
\hline Yüksek Lisans/Doktora & 85 & 15,7 & 51 ve üzeri & 36 & 6,7 \\
\hline Meslek Grupları & $\mathbf{N}$ & $\%$ & Cinsiyet & $\mathbf{N}$ & $\%$ \\
\hline Serbest Meslek & 46 & 8,5 & Kadın & 262 & 48,5 \\
\hline Memur & 114 & 21,1 & Erkek & 278 & 51,5 \\
\hline Sözleşmeli Personel & 29 & 5,4 & Medeni Durum & $\mathbf{N}$ & $\%$ \\
\hline Esnaf & 26 & 4,8 & Evli & 192 & 35,6 \\
\hline Öğrenci & 186 & 34,4 & Bekâr & 348 & 64,4 \\
\hline Ev Hanımı & 37 & 6,9 & Gelir Düzeyi & $\mathbf{N}$ & $\%$ \\
\hline Emekli & 21 & 3,9 & 1500 ve altı & 186 & 34,4 \\
\hline İşçi & 39 & 7,2 & $1501-3000$ & 151 & 28,0 \\
\hline Diğer & 42 & 7,8 & $3001-4500$ & 91 & 16,9 \\
\hline \multirow{2}{*}{ Toplam } & \multirow{2}{*}{540} & \multirow{2}{*}{100} & $4501-6000$ & 51 & 9,4 \\
\hline & & & 6001 ve üstü & 61 & 11,3 \\
\hline
\end{tabular}

Tablo 1'de araştırmaya katılan kadın (262) ve erkek (278) sayısının örneklem içindeki dağılımının birbirine oldukça yakın olduğu, katılımcıların \%64,4'ünün bekâr, \%35,6'sının ise evli olduğu görülmektedir. Araştırmaya katılan sosyal medya kullanıcılarının eğitim durumları incelendiğinde, katılımcıların büyük çoğunluğunu \%56,1 oranı ile üniversite mezunu oluşturmakta olup, bunu \%19,8 ile lise, \%15,7 ile yüksek lisans/doktora ve \%8,3 ile ilköğretim mezunları izlemektedir. Araştırmaya katılanların \%51,9'u 18-28, \%29,6'sı ise 29-39 ve \% 11,9'u 40-50 yaş arasındadır. Gelir düzeylerine bakıldığında araştırmaya katılanların \%34,4'ü 1500TL ve altı, \%28'i 1501TL-3000TL ve \%16,9'u 3001TL-4500TL gelire sahip olduğu görülmektedir. Meslek gruplarında ise araştırmaya katılanların \%34,4'ü öğrenci, \%21,1'i memur olup, serbest meslek, sözleşmeli personel, esnaf, ev hanımı, emekli, işçi ve diğer meslek gruplarının ise yaklaşık \%9 ile \%4 arasında değiştiği görülmektedir. Araştırmaya katılanlara en çok ziyaret ettikleri sosyal paylaşım sitesi ile arkadaş/takip sayıları sorulmuş ve Tablo 2'deki sonuçlar elde edilmiştir.

Tablo 2: Sosyal Paylaşım Sitesi ile Arkadaş/Takip Sayısı Frekans ve Yüzdelik Dağııımları

\begin{tabular}{|c|c|c|c|c|c|}
\hline En Çok Ziyaret Edilen & Frekans & Yüzde Değeri & Arkadaş/Takip Sayısı & Frekans (n) & Yüzde Değeri \\
\hline Facebook & 211 & 39,1 & $1-50$ & 36 & 6,7 \\
\hline Instagram & 192 & 35,6 & $51-100$ & 28 & 5,2 \\
\hline Twitter & 125 & 23,1 & $101-150$ & 53 & 9,8 \\
\hline Diğer & 12 & 2,2 & $151-200$ & 50 & 9,3 \\
\hline \multirow{3}{*}{ Toplam } & & & $201-250$ & 55 & 10,2 \\
\hline & 540 & 100 & 251-300 & 58 & 10,7 \\
\hline & & & 301 ve üzeri & 260 & 48,1 \\
\hline
\end{tabular}

Tablo 2' de araştırmaya katılanların en çok ziyaret ettiği sosyal paylaşım sitesinin sırasıyla $(\% 39,1)$ Facebook, $(\% 35,6)$ Instagram ve $(\% 23,1)$ Twitter olduğu görülmektedir. Tablo 2'de görüldüğü gibi katılımcıların \%48'1'inin en çok ziyaret ettiği sosyal paylaşım sitesindeki arkadaş/takip sayısı 301 ve üzeri kişiden oluşmaktadır. Bunun yanında katılımcıların \%10,7'si 251-300, \%10,2'si 201-250 ve \%5,2'si ise 51-100 arkadaş/takip sayına sahiptir. Genel olarak değerlendirildiğinde araştırmaya katılan sosyal medya kullanıcılarının arkadaş/takip sayılarının oldukça fazla olduğu görülmektedir. 


\section{Araştırma Verilerinin Analizi}

Araştırmada kullanılan ölçeklerin güvenilirlikleri Cronbach Alfa Katsayısı yöntemi, geçerlilikleri ise Faktör Analizi ile test edilmiştir.

\subsection{Araştırmanın Güvenilirliği ve Geçerliliği}

Araştırma kapsamında elde edilen veriler, SPSS programında analiz edilmiş ve anket sorularının güvenilirliğini ölçmek amacıyla güvenilirlik analizi uygulanmıştır. Araştırmada kullanılan ölçeklerin genel alfa değerlerine bakıldığında; Siyasal Pazarlama Sosyal Medya 0,879, Seçmen Güveni 0,799, Seçmen Sadakati 0,800, Seçmen Davranışı 0,831 ve Elektronik Ağızdan Ağıza İletişim ise 0,897 olarak bulunmuştur. Ölçekte yer alan soruların homojen bir yapı gösteren bir bütünü ifade edip etmediğini araştıran Cronbach Alfa Katsayısı, ağırlıklı standart değişim ortalamasıdır. Cronbach Alfa Katsayısı 0 ile 1 arasında değerler alır ve bir ölçekteki soruların varyansları toplamının genel varyansa oranlanması ile elde edilir (Kayış 2010: 405). Alfa katsayısına bağlı olarak ölçeklerin oldukça güvenilir olduğunu söylemek mümkündür.

Araştırmada elde edilen veri setinin, faktör analizi için uygun olup olmadığını belirlemek amacı ile "Barlett Küresellik Testi" ve "Kaiser-Meyer-Olkin Örneklem Yeterlilik Testi" uygulanmıştır. Bartlett küresellik testiyle değişkenler arasında faktör analizi yapmaya yeterli düzeyde ilişki olduğu belirlenmiştir ( $p=0,00<0,05)$. KMO Örneklem Yeterlilik Testi ise, kısmi korelasyon katsayılarının büyüklüğü ile gözlenen korelasyon katsayıları büyüklüğü arasında karşılaştırma yapan bir indekstir ve veri setinin faktör analizi için uygunluğunu göstermektedir (Altunışık vd., 2005: 216; Kalaycı, 2010: 322). Geçerlilik analizi için kullanılan yöntemlerden biri de Faktör Analizi'dir. Faktör Analizi sonucu ölçeğin açıklanan varyansı 0,50 ve üzerinde olduğunda bu ölçeğin yapısal geçerliliğinin iyi düzeyde olduğu söylenebilmektedir (Kalaycı 2010: 330). Araştırma ölçeklerinin geçerlilikleri değerlendirilmek amacıyla faktör analizi yapılmış ve sonuçlar tablolar halinde aşağıda verilmiştir.

Tablo 3: Siyasal Pazarlama Sosyal Medya Ölçeği Faktör Analizi-1

\begin{tabular}{|c|c|c|c|c|c|c|c|}
\hline \multirow[b]{2}{*}{ Bileşen } & \multicolumn{3}{|c|}{ Başlangıç Özdeğeri } & \multicolumn{3}{|c|}{ Faktör Yüklerinin Kareleri Toplamı } & \multirow{2}{*}{$\begin{array}{l}\text { Faktör } \\
\text { Yükü }\end{array}$} \\
\hline & $\begin{array}{l}\text { Top- } \\
\text { lam }\end{array}$ & $\begin{array}{c}\% \text { Var- } \\
\text { yans }\end{array}$ & \% Kümülatif & Toplam $>1$ & \%Varyans & \%Kümülatif & \\
\hline (SPSM1) & 5,053 & 45,933 & 45,933 & 5,053 & 32,739 & 32,739 & ,511 \\
\hline (SPSM2) & 1,154 & 10,495 & 56,427 & 1,154 & 23,689 & 56,427 & 693 \\
\hline (SPSM3) & ,916 & 8,330 & 64,757 & & & & 087 \\
\hline (SPSM4) & ,761 & 6,916 & 71,673 & & & & 184 \\
\hline (SPSM5) & 629 & 5,716 & 77,389 & & & & ,578 \\
\hline (SPSM6) & ,538 & 4,894 & 82,283 & & & & ,245 \\
\hline (SPSM7) & ,479 & 4,357 & 86,640 & & & & ,475 \\
\hline (SPSM8) & ,458 & 4,160 & 90,799 & & & & ,657 \\
\hline (SPSM9) & ,384 & 3,492 & 94,291 & & & & ,738 \\
\hline (SPSM10) & ,341 & 3,098 & 97,389 & & & & 767 \\
\hline (SPSM11) & ,287 & 2,611 & 100,00 & & & & ,804 \\
\hline \multicolumn{4}{|l|}{ KMO: 0,904 } & \multicolumn{3}{|c|}{ Bartlett's Test: 2394,055 p: 0,000} & \\
\hline
\end{tabular}


Tablo 4: Siyasal Pazarlama Sosyal Medya Ölçeği Bileşenler Matrisi

\begin{tabular}{lcc}
\hline Değişkenler & \multicolumn{2}{c}{ Bileşen } \\
\cline { 2 - 3 } & $\mathbf{1}$ & $\mathbf{2}$ \\
\hline SPSM1 &, 511 &, 307 \\
SPSM2 &, 693 &, 299 \\
SPSM3 &, 087 &, 805 \\
SPSM4 &, 184 &, 637 \\
SPSM5 &, 578 &, 567 \\
SPSM6 &, 245 &, 726 \\
SPSM7 &, 475 &, 435 \\
SPSM8 &, 657 &, 457 \\
SPSM9 &, 738 &, 237 \\
SPSM10 &, 767 &, 227 \\
SPSM11 &, 804 &, 035 \\
\hline
\end{tabular}

Siyasal pazarlama sosyal medya ölçeğinin geçerliliği için yapılan faktör analizi sonuçları Tablo 3'de görülmektedir. Ölçek maddeleri toplam varyansın \%45,933'ünü ve \%10,495'ini açıklayan iki faktör altında gruplanmaktadır. Yapısal eşitliğin test edilebilmesi için ölçeklerin tek bir faktör altında gruplanması gerekmektedir. Ölçeklerin tek bir faktör altında gruplanamaması nedeniyle Tablo 4'de belirtilen 2. bileşenlerden faktör yükleri 1. bileşenden fazla olan SPSM3, SPSM4 ve SPSM6 ölçek maddelerinin çıkarılması sonrasında faktör analizi tekrarlanmıştır.

Tablo 5: Siyasal Pazarlama Sosyal Medya Ölçeği Faktör Analizi - 2

\begin{tabular}{lccccccc}
\hline \multirow{2}{*}{ Bileşen } & \multicolumn{3}{c}{ Başlangıç Özdeğeri } & \multicolumn{2}{c}{ Faktör Yüklerinin Kareleri Toplamı } & Faktör \\
\cline { 2 - 6 } & $\begin{array}{c}\text { Top- } \\
\text { lam }\end{array}$ & $\begin{array}{c}\text { \%Var- } \\
\text { yans }\end{array}$ & \% Kümülatif & Toplam>1 & \%Varyans & \%Kümülatif & Yükü \\
\hline (SPSM1) & 4,248 & 53,094 & 53,094 & 4,248 & 53,094 & 53,094 &, 616 \\
(SPSM2) &, 923 & 11,533 & 64,628 & & &, 763 \\
(SPSM5) &, 719 & 8,993 & 73,621 & & &, 787 \\
(SPSM7) &, 582 & 7,278 & 80,899 & & &, 643 \\
(SPSM8) & ,492 & 6,149 & 87,048 & & &, 796 \\
(SPSM9) &, 387 & 4,842 & 91,890 & & &, 752 \\
(SPSM10) &, 358 & 4,472 & 96,361 & & &, 673 \\
(SPSM11) & ,291 & 3,639 & 100,000 & & & \\
\hline
\end{tabular}

Faktör analizinin tekrarlanması neticesinde siyasal pazarlama sosyal medya bileşenleri faktör yüklerinin Tablo 5'de belirtildiği şekilde oluştuğu görülmektedir. Dolayısıyla Tablo 5'de ölçek maddelerinin hepsinin toplam varyansın \%53.094'ünü açıklayacak şekilde tek bir faktör altında gruplanabildiği görülmekte olup, ölçek geçerli hale gelmiştir. Ayrıca KMO $>0.5$ ve Bartlett $p<0.05$ olması verilerin faktör analizi için uygun olduğunu göstermektedir. 
Eskişehir Osmangazi Üniversitesi iiBF Dergisi

Tablo 6: Seçmen Güveni, Seçmen Sadakati, Seçmen Davranışı ve EAAi Ölçeği Faktör Analizi

\begin{tabular}{|c|c|c|c|c|c|c|c|}
\hline \multirow{2}{*}{ Bileşen } & \multicolumn{3}{|c|}{ Başlangıç Özdeğeri } & \multicolumn{3}{|c|}{ Faktör Yüklerinin Kareleri Toplamı } & \multirow{2}{*}{$\begin{array}{l}\text { Faktör } \\
\text { Yükü }\end{array}$} \\
\hline & Toplam & \%Varyans & \% Kümülatif & Toplam>1 & \%Varyans & \%Kümülatif & \\
\hline (SG1) & 2,139 & 71,304 & 71,304 & 2,139 & 71,304 & 71,304 & ,681 \\
\hline (SG2) & ,474 & 15,785 & 87,089 & & & & ,714 \\
\hline (SG3) & ,387 & 12,911 & 100,000 & & & & ,744 \\
\hline \multicolumn{3}{|c|}{ KMO: 0,706} & & \multicolumn{3}{|c|}{ Bartlett's Test: 502,554 p: 0,000} & \\
\hline (SS1) & 2,146 & 71,542 & 71,542 & 2,146 & 71,542 & 71,542 & ,758 \\
\hline (SS2) & ,515 & 17,177 & 88,719 & & & & ,750 \\
\hline (SS3) & ,338 & 11,281 & 100,000 & & & & ,638 \\
\hline \multicolumn{3}{|c|}{ KMO: 0,693 } & & \multicolumn{3}{|c|}{ Bartlett's Test: 527,861 p: 0,000} & \\
\hline (SD1) & 2,243 & 74,757 & 74,757 & 2,243 & 74,757 & 74,757 & ,789 \\
\hline (SD2) & ,463 & 15,444 & 90,201 & & & & ,777 \\
\hline (SD3) & ,294 & 9,799 & 100,000 & & & & 677 \\
\hline \multicolumn{3}{|c|}{ KMO: 0,706} & & \multicolumn{3}{|c|}{ Bartlett's Test: 637,038 p: 0,000} & \\
\hline (EAA1) & 2,488 & 82,933 & 82,933 & 2,488 & 82,933 & 82,933 & ,803 \\
\hline (EAA2) & ,309 & 10,312 & 93,245 & & & & 867 \\
\hline (EAA3) & ,203 & 6,755 & 100,000 & & & & 818 \\
\hline \multicolumn{3}{|c|}{ KMO: 0,738} & & \multicolumn{3}{|c|}{ Bartlett's Test: 998,079 p: 0,000 } & \\
\hline
\end{tabular}

Tablo 6'da ölçek maddelerinin sırasıyla toplam varyansın \%71,304'ünü, \%71,542'sini, $\% 74,757$ 'sini ve \%82,933'ünü açıklayan tek bir faktör altında gruplandığı görülmektedir. Bu nedenle ölçeklerden herhangi bir maddenin çıkarılması gerekmemektedir. Ayrıca KMO>0.5, ve Bartlett $p<0.05$ olması verilerin faktör analizi için uygun olduğunu göstermektedir.

\subsection{Araştırma Hipotezlerinin Test Edilmesi}

Sosyal bilim alanında araştırma yapan, çok değişkenli istatistiksel tekniklerin birleşiminden meydana gelen, güçlü bir analiz yöntemi olan Yapısal Eşitlik Modeli sebep, sonuç ilişkilerini açıklayabilen, bütün olarak teorik modellerin test edilmesine olanak sağlayan model test etme ve geliştirme yöntemi olarak tanımlanmaktadır (Ayyıldız ve Cengiz, 2006: 63). Yapısal Eşitlik Modeli ilgili literatürün incelenmesi, modelin belirlenmesi, kimliğinin tanımlanması, ölçeklerin seçilmesi, verilerin toplanması ve tanımlayıcı analizlerin yapılması, modeldeki parametrelerin hesaplanması, modelin uygunluğunun araştırılması ve sonuçların değerlendirilmesi süreçlerinden oluşmaktadır (Suhr, 2006: 2). Gizil değişkenlerin bulunduğu doğrusal yapı eşitlik setindeki bilinmeyen parametreleri tahmin etmek için kullanılan bu model, gizil değişkenlerin gözlenen değişkenler aracılığı ile ölçülebileceğini varsaymaktadır (Yılmaz, 2004: 783; Yılmaz vd., 2006: 175). Bu kapsamda araştırmanın yapısal eşitlik modeli sonucu Şekil 2'de görüldüğü gibidir. 


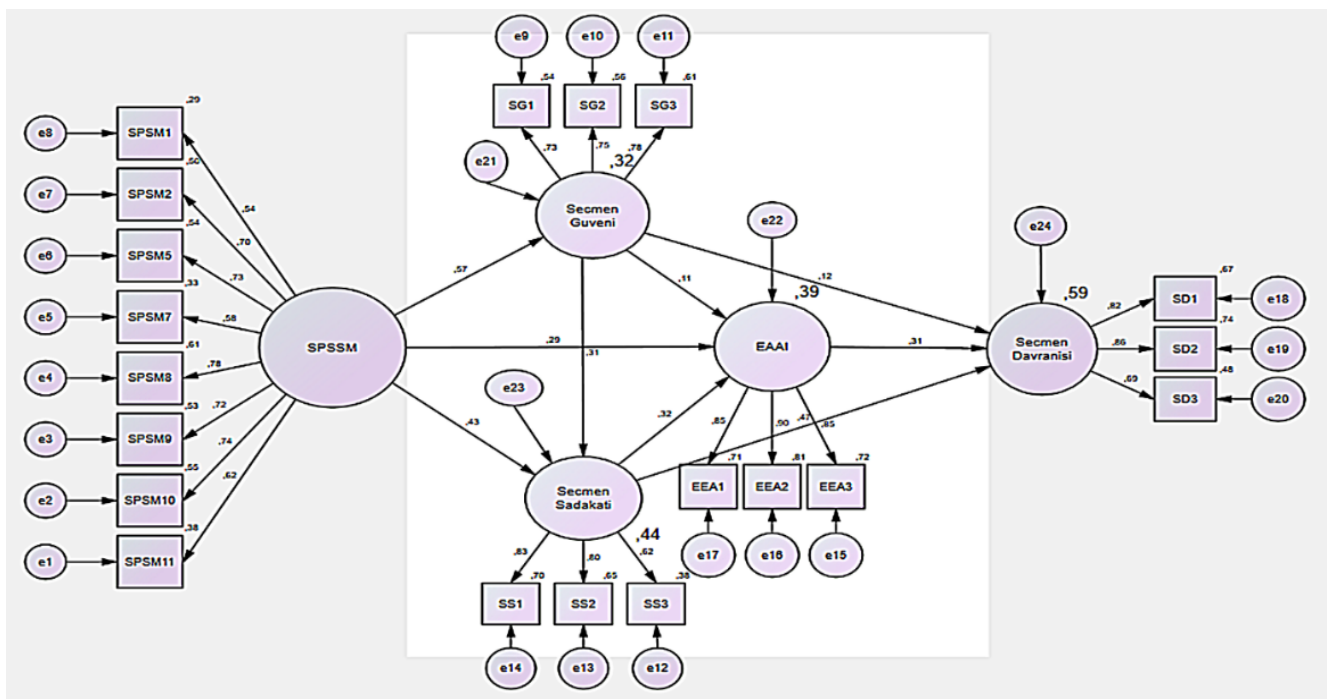

Şekil 2: Yapısal Eşitlik Modeli Sonucu-1

Araştırma modelinin kabul veya red edilmesi kararının verildiği aşama olan uyum iyiliği testleri teorik modelin elde edilen veriyi ne kadar iyi açıkladığını belirlemek için kullanılmaktadır. Çok fazla uyum iyiliği indeksleri olduğu, ancak her hangi bir model açıklanırken bunlardan en az 4 en fazla 8 tanesinin kullanıldığı ifade edilmektedir (Ayyıldız ve Cengiz, 2006: 77). Bu kapsamda araştırma modeli literatürde en çok kullanılan, Tablo 7'de belirtilen mükemmel ve kabul edilebilir uyum iyiliği değerleri (ilhan ve Çetin, 2014: 31) dikkate alınarak değerlendirilmiştir.

Tablo 7: Araştırma Modelinin Uyum Iyiliği Indeksleri-1

\begin{tabular}{|c|c|c|c|}
\hline Model Uyum İndeksi & $\begin{array}{c}\text { Mükemmel Uyum } \\
\text { Değeri }\end{array}$ & $\begin{array}{c}\text { Kabul Edilebilir } \\
\text { Uyum Değeri }\end{array}$ & $\begin{array}{c}\text { Model Uyum } \\
\text { Değeri }\end{array}$ \\
\hline X2 Ki-Kare değeri & & & 515,165 \\
\hline DF Serbestlik Derecesi & & & 161 \\
\hline P Anlamlılık Düzeyi & & & 0,000 \\
\hline$\chi 2 / d f$ & $0 \leq x 2 / s d \leq 2$ & $\chi 2 / \mathrm{df} \leq 3$ & 3,200 \\
\hline RMSEA Yaklaşım Hatasının Kök Ortalama Karesi & $.00 \leq \mathrm{RMSEA} \leq .05$ & $.05 \leq$ RMSEA $\leq .08$ & 0,064 \\
\hline RFI Göreceli Uyum İyiliği İndeksi & $.95 \leq \mathrm{RFI} \leq 1.00$ & $.90 \leq \mathrm{RFI} \leq .95$ & 0,893 \\
\hline GFI Uyum İyiliği İndeksi & $.95 \leq \mathrm{GFI} \leq 1.00$ & $.90 \leq \mathrm{GFI} \leq 95$ & 0,909 \\
\hline AGFI Düzeltilmiş Uyum İyiliği İndeksi & $.90 \leq \mathrm{AGFI} \leq 1.00$ & $.85 \leq \mathrm{AGFI} \leq .90$ & 0,881 \\
\hline CFI Karşılaştırmalı Uyum İyiliği İndeksi & $.95 \leq \mathrm{CFI} \leq 1.00$ & $.90 \leq \mathrm{CFI} \leq .95$ & 0,936 \\
\hline NFI Normlaştırılmış Uyum İyiliği İndeksi & $.95 \leq \mathrm{NFI} \leq 1.00$ & $.90 \leq \mathrm{NFI} \leq .95$ & 0,909 \\
\hline IFI Artırımlı Uyum İyiliği İndeksi & $.95 \leq \mathrm{IFI} \leq 1.00$ & $.90 \leq \mathrm{IFI} \leq .95$ & 0,936 \\
\hline
\end{tabular}

Araştırmanın hipotezlerine ilişkin yapısal eşitlik modeli sonuçlarını gösteren Tablo 7 incelendiğinde Model 1'in uyum indeksi sonuçlarının (X2/df: 3,200, P: 0,000, RMSEA:0,064, RFI:0,893, GFI:0,909, AGFI.0,881, CFI:0,936, NFI:0,909, IFI:0,936) oldukça iyi olduğu görülmektedir. Ancak modele ait en iyi uyumu elde etmek için modifikasyon yapılmış olup, Model 2'ye ait sonuçlar Şekil 3'de ve Tablo 8'de verilmiştir. 


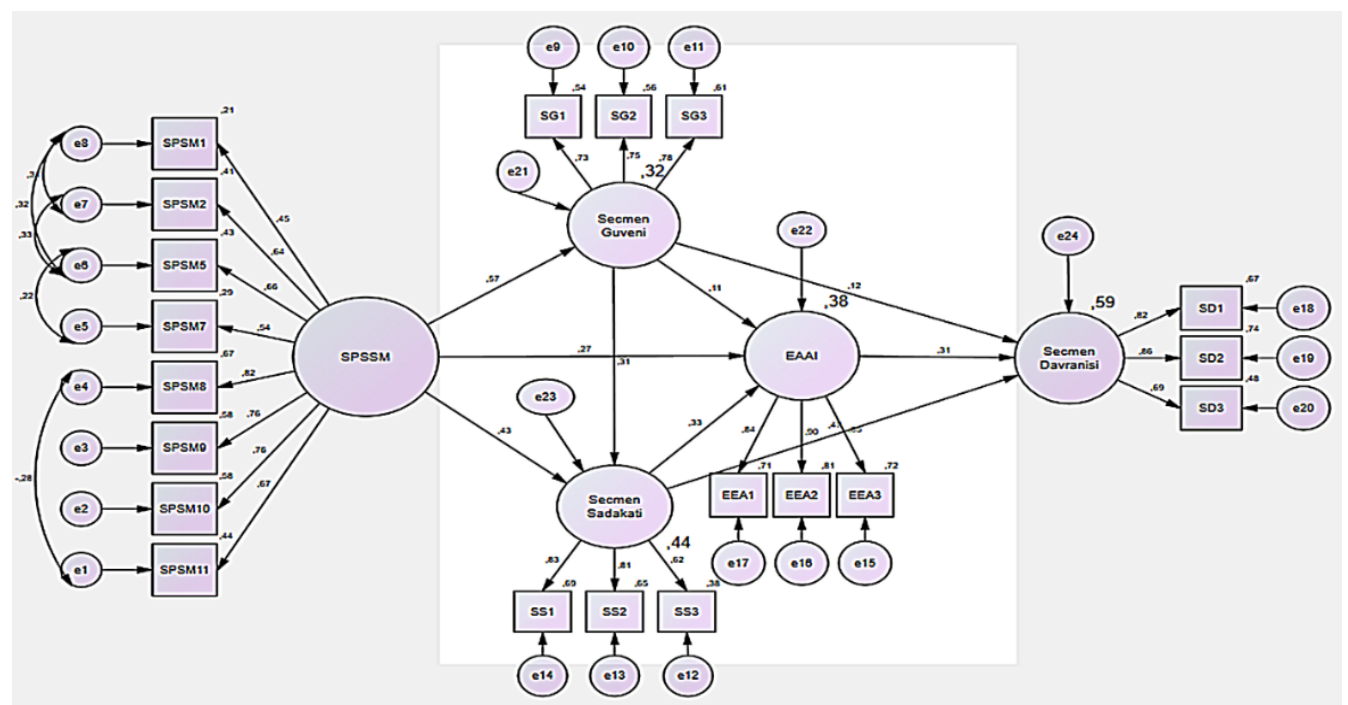

Şekil 3. Yapısal Eşitlik Modeli Sonucu-2

Tablo 8: Araştırma Modelinin Uyum Iyiliği Indeksleri-2

\begin{tabular}{|c|c|c|c|}
\hline Model Uyum İndeksi & $\begin{array}{c}\text { Mükemmel Uyum } \\
\text { Değeri }\end{array}$ & $\begin{array}{l}\text { Kabul Edilebilir } \\
\text { Uyum Değeri }\end{array}$ & $\begin{array}{c}\text { Model Uyum } \\
\text { Değeri }\end{array}$ \\
\hline X2 Ki-Kare değeri & & & 357,579 \\
\hline DF Serbestlik Derecesi & & & 156 \\
\hline P Anlamlılık Düzeyi & & & 0,000 \\
\hline$\chi 2 / \mathrm{df}$ & $0 \leq \chi 2 / s d \leq 2$ & $x 2 / d f \leq 3$ & 2,292 \\
\hline RMSEA Yaklaşım Hatasının Kök Ortalama Karesi & $.00 \leq \mathrm{RMSEA} \leq .05$ & $.05 \leq \mathrm{RMSEA} \leq .08$ & 0,049 \\
\hline RFI Göreceli Uyum İyiliği İndeksi & $.95 \leq \mathrm{RFI} \leq 1.00$ & $.90 \leq \mathrm{RFI} \leq .95$ & 0,923 \\
\hline GFI Uyum İyiliği İndeksi & $.95 \leq \mathrm{GFI} \leq 1.00$ & $.90 \leq \mathrm{GFI} \leq 95$ & 0,939 \\
\hline AGFI Düzeltilmiş Uyum İyiliği İndeksi & $.90 \leq \mathrm{AGFI} \leq 1.00$ & $.85 \leq \mathrm{AGFI} \leq .90$ & 0,918 \\
\hline CFI Karşılaştırmalı Uyum İyiliği İndeksi & $.95 \leq \mathrm{CFI} \leq 1.00$ & $.90 \leq \mathrm{CFI} \leq .95$ & 0,963 \\
\hline NFI Normlaştırılmış Uyum İyiliği İndeksi & $.95 \leq \mathrm{NFI} \leq 1.00$ & $.90 \leq \mathrm{NFI} \leq .95$ & 0,937 \\
\hline IFI Artırımlı Uyum İyiliği İndeksi & $.95 \leq \mathrm{IFI} \leq 1.00$ & $.90 \leq \mathrm{IFI} \leq .95$ & 0,964 \\
\hline
\end{tabular}

Yapısal Eşitlik Modelinin verilere uygun ve doğrulanabilir olması için gözlenen veriler ile teorik veriler arasında bir farkın olmaması gerekmektedir. Bu nedenle modelin parçaları hakkında bilgi veren ve orijinal değişken matrisinin varsayılan matristen farklı olup olmadığını test eden $x^{2}$ değerinin düşük olması arzu edilmektedir. Yapılan modifikasyon sonrası araştırmada $x^{2}$ değerinin $\left(x^{2}=357.579, p=0,000\right)$ anlamlı ve makul seviyede çıktığı görülmektedir. Modelin kabulü için değerlendirilen bir diğer ölçek ise $\chi 2 / d f^{\prime}$ dir. Veri ile model arasındaki uyumu değerlendirmede kullanılan kriterlerden birisi olan $\chi 2 / \mathrm{df}^{\prime}$ nin (ki-kare/serbestlik derecesi) sıfıra yakın olması veya $5^{\prime}$ in altında bir değer alması gerekmektedir. Söz konusu $\chi 2 / d f$ değeri 2,292 olup, 5'ten küçük ve kabul edilebilir bir değerdir. En iyi uyumu elde edebilmek için yapılan modifikasyon neticesinde Model 2'in uyum indeksi sonuçlarının Tablo 9'da belirtildiği üzere (RMSEA:0,049, RFI:0,923, GFI:0,939, AGFI.0,918, CFI:0,963, NFI:0,937, IFI:0,964) büyük oranda değiştiği görülmektedir. Araştırma modelinin bu değerlerle birlikte daha iyi bir uyuma sahip olduğu söylenebilmektedir. Araştırma hipotezlerine yönelik değerlendirme yapabilmek için regresyon katsayılarını incelemek gerekmektedir. Yapısal model, gizil değişkenler arasındaki ilişkiyi ölçen eşitlik olarak bilinmektedir. Şekil 3'de görüldüğü gibi yapısal modelde (SPSM dışsal gizil değişken, seçmen güveni, seçmen sadakati, EAAI ve seçmen davranışı içsel gizil değişken olmak üzere) 5 adet 
gizil değişken bulunmaktadır. Gizil değişkenler arasındaki yön okları bağımsız değişkendeki bir standart birimlik değişimin bağımlı değişkende kaç standart birimlik bir değişime neden olacağını (standart regresyon katsayısı) göstermektedir. Tablo 9'da araştırma hipotezleri ile ilgili bütün regresyon katsayıları verilmiştir.

Tablo 9: Regresyon Katsayıları

\begin{tabular}{lllcccc}
\hline Regresyon Yönü & & & $\begin{array}{c}\text { Standardize } \\
\text { Edilmemiş } \\
\text { Regresyon Katsayısı }\end{array}$ & $\begin{array}{c}\text { Standart } \\
\text { Regresyon } \\
\text { Katsayısı }\end{array}$ & $\begin{array}{c}\text { Standart } \\
\text { Hata }\end{array}$ & $\begin{array}{c}\text { Anlamlı- } \\
\text { lık Dü- } \\
\text { zeyi }\end{array}$ \\
\hline Seçmen Güveni & $<---$ & SPSSM & 0,586 & 0,569 & 0,062 & 0,000 \\
Seçmen Sadakati & $<---$ & SPSSM & 0,327 & 0,430 & 0,048 & 0,000 \\
Seçmen Sadakati & $<---$ & Seçmen Güveni & 0,231 & 0,313 & 0,045 & 0,000 \\
EAAI & $<---$ & Seçmen Güveni & 0,137 & 0,111 & 0,073 & 0,061 \\
EAAI & $<---$ & Seçmen Sadakati & 0,552 & 0,330 & 0,108 & 0,000 \\
Seçmen Davranışı & $<---$ & Seçmen Güveni & 0,127 & 0,116 & 0,057 & 0,026 \\
Seçmen Davranışı & $<---$ & Seçmen Sadakati & 0,697 & 0,471 & 0,097 & 0,000 \\
EAAI & $<---$ & SPSSM & 0,347 & 0,273 & 0,078 & 0,000 \\
Seçmen Davranışı & $<---$ & EAAI & 0,274 & 0,310 & 0,044 & 0,000 \\
\hline
\end{tabular}

Yapısal Eşitlik Modelinde çoklu ölçümlerle ilişkilendirilen her bir gizil değişkenler gözlenen değişkenlere faktör analizi yöntemiyle bağlıdır. YEM ile gözlenen değişkenler aracılığı ile gizil değişkenlerin ölçülebilmesi nedeniyle gözlenen değişkenlerin gizil değişkenleri ne kadar açıklayabildikleri önemlidir. Her bir gizil değişkenin ölçümüne katkı sağlayan gözlenen değişkenler tarafından açıklanma durumu Yapısal Eşitlik Modelinde dikkate alınmaktadır. Tablo 10'da araştırma değişkenlerinin faktör yükleri gösterilmektedir.

Tablo 10: Standart Faktör Yükleri

\begin{tabular}{llll}
\hline & \multicolumn{1}{c}{ Faktör } & Faktör Yükü \\
\hline SPSM1 & $<---$ & Siyasal Pazarlama Sosyal Medya & 0,453 \\
SPSM2 & $<---$ & Siyasal Pazarlama Sosyal Medya & 0,643 \\
SPSM5 & $<---$ & Siyasal Pazarlama Sosyal Medya & 0,659 \\
SPSM7 & $<---$ & Siyasal Pazarlama Sosyal Medya & 0,543 \\
SPSM8 & $<---$ & Siyasal Pazarlama Sosyal Medya & 0,816 \\
SPSM9 & $<---$ & Siyasal Pazarlama Sosyal Medya & 0,759 \\
SPSM10 & $<---$ & Siyasal Pazarlama Sosyal Medya & 0,762 \\
SPSM11 & $<---$ & Siyasal Pazarlama Sosyal Medya & 0,665 \\
SG1 & $<---$ & Seçmen Güveni & 0,733 \\
SG2 & $<---$ & Seçmen Güveni & 0,751 \\
SG3 & $<---$ & Seçmen Güveni & 0,782 \\
SS1 & $<---$ & Seçmen Sadakati & 0,833 \\
SS2 & $<---$ & Seçmen Sadakati & 0,807 \\
SS3 & $<---$ & Seçmen Sadakati & 0,619 \\
EEA1 & $<---$ & EAAl & 0,845 \\
EEA2 & $<---$ & EAAI & 0,901 \\
EEA3 & $<---$ & EAAl & 0,847 \\
SD1 & $<---$ & Seçmen Davranışı & 0,818 \\
SD2 & $<---$ & Seçmen Davranışı & 0,859 \\
SD3 & $<---$ & Seçmen Davranışı & 0,689 \\
\hline
\end{tabular}


Her bir gizil değişkenin gözlenen değişkenler tarafından ne doğrulukta ve ne kadar açıklandığı konusunun önemli olması nedeniyle YEM'de açıklayıcı faktör analizi yerine doğrulayıcı faktör analizi tercih edilmektedir. Araştırma modelindeki değişkenlere ait faktör yükleri Tablo 10 'da görülmektedir. Tablo 11'de gizil değişkenlere ait doğrudan ve dolaylı ilişkiler gösterilmektedir.

Tablo 11: Yapısal Eşitlik Modelindeki Gizli Değişkenler Arası Doğrudan ve Dolaylı Iilişkiler

\begin{tabular}{|c|c|c|c|c|c|c|c|c|c|c|c|c|}
\hline \multirow[b]{2}{*}{ Değişken } & \multicolumn{3}{|c|}{ Seçmen Güveni } & \multicolumn{3}{|c|}{ Seçmen Sadakati } & \multicolumn{3}{|c|}{ EAAI } & \multicolumn{3}{|c|}{ Seçmen Davranışı } \\
\hline & $\begin{array}{c}\text { Doğ- } \\
\text { rudan }\end{array}$ & $\begin{array}{l}\text { Do- } \\
\text { laylı }\end{array}$ & $\begin{array}{l}\text { Top- } \\
\text { lam }\end{array}$ & $\begin{array}{l}\text { Doğ- } \\
\text { rudan }\end{array}$ & $\begin{array}{l}\text { Do- } \\
\text { laylı }\end{array}$ & $\begin{array}{l}\text { Top- } \\
\text { lam }\end{array}$ & $\begin{array}{l}\text { Doğ- } \\
\text { rudan }\end{array}$ & $\begin{array}{l}\text { Do- } \\
\text { laylı }\end{array}$ & $\begin{array}{l}\text { Top- } \\
\text { lam }\end{array}$ & $\begin{array}{l}\text { Doğ- } \\
\text { rudan }\end{array}$ & $\begin{array}{l}\text { Do- } \\
\text { laylı }\end{array}$ & $\begin{array}{l}\text { Top- } \\
\text { lam }\end{array}$ \\
\hline SPSM & 0,569 & & 0,569 & 0,430 & 0,135 & 0,565 & 0,273 & 0,335 & 0,608 & & 0,583 & 0,583 \\
\hline SG & & & & 0,313 & & 0,313 & 0,111 & 0,127 & 0,238 & 0,116 & 0,233 & 0,349 \\
\hline SS & & & & & & & 0,330 & & 0,330 & 0,471 & 0,151 & 0,622 \\
\hline EAAi & & & & & & & & & & 0,310 & & 0,310 \\
\hline SD & & & & & & & & & & & & \\
\hline
\end{tabular}

Tablo 11'de 0.05 anlamlılık düzeyinde önemli görülen gizli değişkenler arası doğrudan ve dolaylı ilişkiler görülmektedir. Tablo 11'e göre neticelendirilen araştırmanın Yapısal Eşitlik Modeli hipotez testi sonuçları Tablo 12'de verilmiştir.

Tablo 12: Yapısal Eşitlik Modeli Hipotez Testi Sonuçları

\begin{tabular}{lc}
\hline \multicolumn{1}{c}{ Hipotez } & Sonuç \\
\hline $\begin{array}{l}\text { H1: Siyasal pazarlama sosyal medya faktörünün seçmen güveni üzerinde doğrudan } \\
\text { etkisi vardır. }\end{array}$ & $\begin{array}{c}(r=0,569 p=0,000) \\
\text { KABUL }\end{array}$ \\
H2: Siyasal pazarlama sosyal medya faktörünün seçmen sadakati üzerinde doğru- \\
dan ve dolaylı etkisi vardır. & $(r=0,430+0,135 p=0,000)$ \\
KABUL & $(r=0,313 p=0,000)$ \\
H3: Seçmen güveninin seçmen sadakati üzerinde doğrudan etkisi vardır. & KABUL \\
H4: Seçmen güveninin elektronik ağızdan ağıza iletişim üzerinde doğrudan ve do- & $(r=0,111+0,127 p=0,061)$ \\
laylı etkisi vardır. & RED \\
H5: Seçmen sadakatinin elektronik ağızdan ağıza iletişim üzerinde doğrudan etkisi & $(r=0,330 p=0,000)$ \\
vardır. & $K A B U L$ \\
H6: Seçmen güveninin seçmen davranışı üzerinde doğrudan ve dolaylı etkisi vardır. & $(r=0,116+0,233 p=0,026)$ \\
H7: Seçmen sadakatinin seçmen davranışı üzerinde doğrudan ve dolaylı etkisi var- & KABUL \\
dır. & $(r=0,471+0,151 p=0,000)$ \\
H8: Siyasal pazarlama sosyal medya faktörünün elektronik ağızdan ağıza iletişim & KABUL \\
üzerinde doğrudan ve dolaylı etkisi vardır. & $(r=0,273+0,335 p=0,000)$ \\
H9: Elektronik ağızdan ağıza iletişim faktörünün seçmen davranışı üzerinde doğru- & KABUL \\
dan etkisi vardır. & $(r=0,310 p=0,000)$ \\
\end{tabular}

Literatürde güven ve elektronik ağızdan ağıza iletişim arasında pozitif yönde ilişki bulunan çalışmalara rastlamak mümkündür. Ancak bu çalışmanın konusunun siyasal pazarlama olması ve sosyal medya kullanıcılarına yönelik yapılması nedeniyle katılımcıların sosyal medya platformlarında siyasal anlamda elektronik ağızdan ağıza iletişim yapmaları için sadece güven faktörünün yeterli olmayacağı düşünülebilir. Gizli değişkenler arası doğrudan ve dolaylı ilişkiyi gösteren regresyon değerine göre seçmen güveni ile elektronik ağızdan ağıza iletişim arasında $(r=0,111+0127)$ ilişki görülsede $(p=0,061) 0.05$ anlamlılık düzeyinde seçmen güveninin elektro- 
nik ağızdan ağıza iletişim üzerinde etkili olduğu söylenememektedir. Dolayısıyla Tablo 12 'de görüldüğü gibi araştırmanın yapısal modeli ile ilgili oluşturulan hipotezlerden $\mathrm{H} 4$ red edilmiş olup, diğer tüm hipotezler kabul edilmiştir.

\section{Sonuç}

Teknolojik gelişmeler kar amacı olan ya da olmayan bütün kurumların pazarlama faaliyetlerini etkin bir şekilde kullanmalarına olanak sağlamaktadır. Temel amacı seçmenlerin desteğini alarak seçim kazanmak olan siyasi adayların veya partilerin siyasal pazarlama faaliyetlerinde bulundukları, gelişen teknolojiden faydalanarak kitlelere ulaşmaya çalıştıkları söylenebilmektedir. Özellikle günümüzde toplumun bilgi düzeyi ve yoğun rekabet ortamı nedeniyle siyasi kurumların pazarlama faaliyetlerine daha fazla ihtiyaç duyduğu, stratejik hedeflerini gerçekleştirmek için metodolojik ve bilimsel yaklaşımlara yönelmeleri gerektiği söylenebilmektedir. Bu kapsamda sosyal medya platformları pazarlama iletişimi için stratejik bir pazarlama aracı olarak kullanılmaktadır.

Siyasi adaylar veya partiler özellikle seçim dönemlerinde adaylarını ve partilerini teşvik etmek, piyasada olumlu bir şekilde konumlandırmak ve seçmenlerin desteğini kazanmak için pazarlama stratejilerinin bir parçası olarak sosyal medyadan yararlanmaktadırlar. Sosyal paylaşım siteleri ile siyasal faaliyetler hakkındaki bilgiler seçmenlere ulaştırılmaya çalışılmaktadır. Seçmenler arasında gerçekleşen elektronik ağızdan ağıza iletişim neticesinde bu bilgiler daha güvenilir bir şekilde bir biriyle etkileşim kuran kişiler arasında hızlıca yayılabilmektedir. Bu bağlamda siyasal pazarlama sürecinde sosyal medyanın sunduğu imkânlardan yararlanmanın günümüz rekabet ortamında oldukça önemli olduğu görülmektedir.

Bu çalışmada siyasal pazarlama sosyal medya faktörünün seçmen güveni ve sadakati üzerindeki etkileri ile seçmen güveni, sadakatinin elektronik ağızdan ağıza iletişim ve seçmen davranışına etkileri belirlenmeye çalışılmıştır. Siyasal pazarlama sosyal medya faktörünün seçmen güveni üzerinde doğrudan, seçmen sadakati üzerinde ise doğrudan ve dolaylı, seçmen güveninin seçmen sadakati üzerinde doğrudan etkisinin olduğu sonucuna ulaşılmıştır. Araştırma neticesinde seçmen sadakatinin ise elektronik ağızdan ağıza iletişim üzerinde doğrudan, seçmen güveninin seçmen davranışı üzerinde doğrudan ve dolaylı, seçmen sadakatinin seçmen davranışı üzerinde doğrudan ve dolaylı etkisinin olduğu tespit edilmiştir. Siyasal pazarlama sosyal medya faktörünün, elektronik ağızdan ağıza iletişim üzerinde doğrudan ve dolaylı, seçmen davranışı üzerinde dolaylı, elektronik ağızdan ağıza iletişimin ise seçmen davranışı üzerinde doğrudan etkisinin olduğu sonucuna ulaşılmıştır.

Yukarıda belirtilen sonuçlara göre, siyasi parti veya liderleri tarafından sosyal paylaşım sitelerinden yapılan siyasi içerikli paylaşımlara sosyal medya kullanıcılarının güven duydukları, bu güvenin onların sadakatlerine doğrudan ve dolaylı etki ettiği söylenebilmektedir. Tüketici davranışlarında hayati bir rol oynayan sadakatin siyasal anlamda sosyal paylaşım sitelerinde yapılan elektronik ağızdan ağıza iletişime etki ettiği ve bütün bu faktörlerin seçmenlerin davranışlarında değişikliğe neden olabileceği söylenebilmektedir. Bu anlamda siyasi adayların veya partilerin pazarlama iletişimi için sosyal medya platformlarını kullanırken adaylarını veya partilerini teşvik etmek, onları piyasada olumlu bir şekilde konumlandırmak ve seçmenlerin desteğini kazanmak için stratejik bir pazarlama aracı olarak sosyal medyayı etkin bir şekilde kullanmaları gerektiğini söylemek mümkündür. 


\section{Eskişehir Osmangazi Üniversitesi iiBF Dergisi}

\section{Kaynaklar}

Agyapong, Gloria K. Q. (2011), "The Effect of Service Quality on Customer Satisfaction in the Utility Industry- A Case of Vodafone", International Journal of Business and Management, Vol. 6, No. 5: 203-210.

Ahmed, Mirza Ashfaq; Lodhi Suleman; Shahzad Mirza Naveed (2011), "Political Brand: Trusting a Candidate in the Age of Mistrust", Journal of Business \& Retail Management Research, Vol.5, No. 2: 131-141.

Ahrens, Jan; Cooyle, James R.; Strahileittz, Michal (2013), "Electronic Word of Mouth: The Effects of Incentives on EReferrals by Senders and Receivers", European Journal of Marketing, Vol. 47, No. 7: 1034-1051.

Akgün, Birol (2007), Türkiye'de Seçmen Davranışı, Partiler Sistemi ve Siyasal Güven, Nobel Yayın Dağıtım, Ankara: Sözcü Kitabevi.

Altunışık, Remzi; Coşkun, Recai; Bayraktaroğlu, Serkan; Yıldırım, Engin (2005), Sosyal Bilimlerde Araştırma Yöntemleri SPSS Uygulamalı, İstanbul: Sakarya Kitabevi.

American Marketing Association, (AMA) https://www.ama.org/AboutAMA/Pages/Definition-of-Marketing.aspx (Erişim: 05.04.2018)

Anderson Erin; Weitz, Barton (1989), "Determinants of Continuity in Conventional Industrial Channel Dyads", Marketing Science, Vol. 8, No. 4: 310-323.

Argan, Metin; Argan, Mehpare Tokay (2012), “Word-of-Mouth (WOM): Voters Originated Communications on Candidates During Local Elections", International Journal of Business and Social Science, Vol.3, No. 15: 70-77.

Arndt, Johan (1967), "Role of Product-Related Conversations in the Diffusion of a New Product", Journal of Marketing Search, Vol. 4, No. 3: 291-295.

Ayankoya, Kayode A. (2014), "A Framework for the Implementation of Social Media Marketing Strategies in Political Campaigning" Phd thesis, Nelson Mandela Metropolitan University, Port Elizabeth.

Ayyıldız, Hasan; Cengiz, Ekrem (2006), “Pazarlama Modellerinin Testinde Kullanılabilecek Yapısal Eşitlik Modeli (YEM) Üzerine Kavramsal Bir İnceleme”, Süleyman Demirel Üniversitesi İktisadi ve Idari Bilimler Fakültesi Dergisi, C. 11, S. 2: 63-84.

Baines, Paul R.; Harris Phil; Lewis Barbara R. (2002), "The Political Marketing Planning Process: Improving Image and Message in Strategic Target Areas", Marketing Intelligence \& Planning, Vol. 20, No. 1: 6-14.

Balakrishnan, Bamini KPD; Dahnil, Mohd Irwan; Jiunn, YI Wong (2014), “The Impact of Social Media Marketing Medium Toward Purchase Intention and Brand Loyalty Among Generation Y", Procedia - Social and Behavioral Sciences, No. 148: 177-185.

Barış, Gülfidan (2009), "Partizan Seçmenler, Kararsız Seçmenler ve Gezen Oylar”, (Ed. Abdullah Özkan), Siyasetin Iletişimi, İstanbul: Tasam Yayınları, 69-84.

Başarır, Murat (2016), "Seçmenlerin Oy Verme Davranışları ile Liderlerin Hitaplarında Aradıkları İkna Bileşenleri ve Uslup Çeşitleri Arasındaki İlişki”, Inönü Üniversitesi Illetişim Fakültesi Elektronik Dergisi (iNiF E-Dergi), C. 1, S. 2: 218233.

Bayrakdaroğlu Funda; Uzun, Turgay; Özkoç, Hatice Hicret (2016), “Siyasal Pazarlama Kapsamında Seçmenlerin Stratejik Oylama Eğilimleri Üzerine Bir Araştırma: Menteşe Örneği”, Süleyman Demirel Üniversitesi Iktisadi ve Idari Bilimler Fakültesi Dergisi, C. 21, S. 3: 907-922.

Bayraktaroğlu, Gül G. (2002), "Politik Yaşamda Pazarlama Yaklaşımları”, Süleyman Demirel Üniversitesi Iktisadi ve Idari Bilimler Fakültesi Dergisi, C. 7, S. 2: 159-168.

Beren, Fatih (2013), "Seçmen Tercihine Etki Eden Faktörler ve Seçim Güvenliği: Şanlıurfa i̇li Örneği”, Akademik Incelemeler Dergisi, C. 8, S. 1: 191-214.

Bongrand, Michel (1992), "Politikada Pazarlama”, (Çev: Fatoş Ersoy), İstanbul: İletişim Yayınları.

Bozbay, Zehra; Türker, Cansu; Akpınar, Habib Mehmet (2017), “Sosyal Medya Kullanıcılarının Elektronik Güvenleri, Elektronik Bağlıııları ve Elektronik Ağızdan Ağıza İletişimleri Arasındaki illişkilerinin İncelenmesi”, UiiiD-IJEAS, (16. UiK Özel Sayısı), 273-292.

Chiru, Mihail; Gherghina, Sergiu (2012), "When Voter Loyalty Fails: Party Performance and Corruption in Bulgaria and Romania”, European Political Science Review, Vol. 4, No. 1: 29-49.

Chiru Mihail; Gherghina, Sergiu (2012), "When Voter Loyalty Fails: Party Performance and Corruption in Bulgaria and Romania", European Political Science Review, Vol. 4, No. 1: 29-49.

Chu, Shu-Chuan; Kim, Yoojung (2011), “Determinants of Consumer Engagement in Electronic Word-of-Mouth (eWOM) in Social Networking Sites", International Journal of Advertising, Vol. 30, No. 1: 47-75. 
Çatı, Kahraman; Koçoğlu, Cenk Murat; Gelibolu, Levent (2010), “Müşteri Beklentileri ile Müşteri Sadakati Arasındaki İlişki: Beş Yıldızlı Bir Otel Örneği”, Ç.Ü. Sosyal Bilimler Enstitüsü Dergisi, C. 19, S. 1: 429-446.

Çavuşoğlu, Hüseyin; Pekkaya, Mehmet (2016), "Yerel Seçimlerde Genç Seçmenlerin Siyasal Davranışlarına İlişkin Bir İnceleme: Bülent Ecevit Üniversitesi Örneği”, Uluslararası Yönetim Iktisat ve İşletme Dergisi, C. 12, S. 29: 17-40.

Çilingir, Zuhal; Yıldız, Salih; Kurtuldu, Hüseyin Sabri (2010), “Kulaktan Kulağa İletişim: Alışveriş Merkezi Müşterileri Üzerinde Bir Pilot Çalışma”, Atatürk Üniversitesi Iktisadi ve Idari Bilimler Fakültesi, C. 24, S. 3: 95-115.

Çinko, Levent (2006), "Seçmen Davranışları ile Ekonomik Performans Arasındaki ilişkilerin Teorik Temelleri ve Türkiye Üzerine Genel Bir Değerlendirme", Ankara Üniversitesi SBF Dergisi, S. 61-1: 103-116.

Dabula, Nandi (2017), "The Influence of Political Marketing Using Social Media on Trust, Loyalty and Voting Intentıon of the Youth of South Africa", Business \& Social Science Journal (BSSJ), Vol. 2, No. 1: 62-112.

Dellarocas, Chrysanthos (2003), "The Digitization of Word of Mouth: Promise and Challenges of Online Feedback Mechanisms", Management Science, Vol. 49, No.10: 1407-1424.

Digrazia Joseph; McKelvey, Karissa; Bollen, Joahn; Rojas, Fabio (2013), “More Tweets, More Votes: Social Media as a Quantitative Indicator of Political Behavior", PLOS ONE, Vol.8, No. 11:1-5.

Divanoğlu, Sevilay Uslu (2008), "Seçim Kampanyalarında Siyasal Pazarlama Karması Elemanlarının Yeri ve Önemi", Niğde Üniversitesi Iktisadi ve Idari Bilimler Fakültesi Dergisi, C. 1, S. 2: 105-118.

Dursunoğlu, İsmail (2017), "Sosyal Medya ve Siyasal Davranış Illişkisi”, Süleyman Demirel Üniversitesi iktisadi ve Idari Bilimler Fakültesi Dergisi, S. 22: 1579-1585.

Effing, Robin; Hillegersberg, Jos Van; Huibers, Theo (2011), "Social Media and Political Participation: Are Facebook, Twitter and YouTube Democratizing Our Political Systems, Lecture Notes in Computer Science, Vol. 6847: 25-35.

Falkowski, Andrzej; Cwalina, Wojciech (2002), "Structural Models of Voter Behavior in the 2000 Polish Presidential Election", Journal of Political Marketing, Vol. 1, No. 2-3: 137-158.

Gareth, Smith G.; Spotswood, Fiona (2013), "The Brand Equity of the Lib Dems in the 2010 General Election: A National and Local Perspective", Journal of Political Marketing, Vol. 12, No. 2-3: 182-196.

Geetha, Nadarajan; Bojei, Jamil; Khalid, Haliyana (2017), "The Study on Negative eWOM and Its Relationship to Consumer's Intention to Switch Mobile Service Provider", Procedia Computer Science, No. 124: 388-396.

Gefen, David (2000), "E-Commerce: The Role of Familiarity and Trust", Omega, Vol. 28, No. 6: 725-737.

Giasson, Thierry; Lees-Marshment, Jennifer;, Marland Alex (2011), “Introducing Political Marketing” (Ed. Thierry, Giasson; Jennifer, Lees-Marshment), Political Communication in Canada, UBCPress, Toronto: Vancouver, 3-21.

Gillmor, Dan (2004), "We the Media: The Rise of Citizen Journalists", National Civic Review, Vol. 93, No.3: 58-63.

Gökçe, Orhan; Akgün, Birol; Karaçor, Süleyman (2002), “3 Kasım Seçimlerinin Anotomisi: Türk Siyasetinde Süreklilik ve Değişim", Selçuk Üniversitesi İktisadi ve Idari Bilimler Fakültesi Sosyal ve Ekonomik Araştırmalar Dergisi, C. 2, S. 4: 1-44.

Gronroos, Christian (1994), "From Marketing Mix to Relationship Marketing: Towards a Paradigm Shift in Marketing", Management Decision, Vol. 32, No. 2: 4-20.

Hakansson, Peter; Witmer Hope (2015), "Social Media and Trust-A Systematic Literature Review”, Journal of Business and Economics, Vol. 6, No. 3: 517-524.

Harrison-Walker, L. Jean (2001), "The Measurement of Word-of-Mouth Communication and An Investigation of Service Quality and Customer Commitment as Potential Antecedents", Journal of Service Research, No.4: 60-75.

Harrop, Martin; Miller, William L. (1987), “Election and Voters: A Comparative Introduction”, London: McMillan.

Henneberg, Stephan C. (2008), "An Epistemological Perspective on Research in Political Marketing”, Journal of Political Marketing, Vol. 7, No. 2: 151-182.

Hodza, Astrit; Papadopoulou, Katerina; Pavlidou, Vasiliki (2012), “Electronic Word-of-Mouth Through Social Networking Sites”, 1-81. http://Inu.diva-portal.org/smash/get/diva2:530710/FULLTEXT01.pdf (Erişim: 09.03.2018)

Hooghe, Marc; Marien, Sofie; Pauwels, Teun (2011), "Where do Distrusting Voters Turn if There is no Viable Exit or Voice Option? The Impact of Political Trust on Electoral Behaviour in the Belgian Regional Elections of June 2009", Government and Opposition, Vol. 46, No. 2: 245-273.

Horppu, Marianne; Kuıvalainen, Olli; Anssi, Tarkıainen; Ellonen, Hanna-Kaisa (2008), “Online Satisfaction, Trust and Loyalty, and the Impact of the Offline Parent Brand", Journal of Product \& Brand Management, Vol. 17, No. 6: 403413. 


\section{Eskişehir Osmangazi Üniversitesi iiBF Dergisi}

Huang, Travis K.; Liao, Chun-Yung; Wang, Yi-Ting; Lin, Kuan-Yu (2018), “How Does Social Media Interactivity Affect Brand Loyalty", 51st Hawaii International Conference on System Sciences, 2130-2139.

İlhan, Mustafa; Çetin, Bayram (2014), "LISREL ve AMOS Programları Kullanılarak Gerçekleştirilen Yapısal Eşitlik Modeli (YEM) Analizlerine İlişkin Sonuçların Karşılaştırılması", Eğitimde ve Psikolojide Ölçme ve Değerlendirme Dergisi, C. 5, S. 2: 26-42.

Jacoby, Jacob; Kyner, David B. (1973), "Brand Loyalty vs. Repeat Purchasing Behavior”, Journal of Marketing Research, Vol. 10, No. 1: 1-9.

Kalaycı, Şeref (2010), “Faktör Analizi”, (Ed. Şeref KALAYCI), SPSS Uygulamalı Çok Değişkenli İstatistik Teknikleri, Ankara: Asil Yayın Dağıtım, 321-331.

Kayış, Aliye (2010), “Güvenilirlik Analizi (Reliability Analysis)”, (Ed. Şeref KALAYCI), SPSS Uygulamalı Çok Değiş̧kenli istatistik Teknikleri, Asil Yayın Dağıtım, Ankara, 403-419.

Keller, Kevin Lane (1993), “Conceptualizing, Measuring, and Managing Customer-Based Brand Equity”, Journal of Marketing, Vol. 57, No. 1: 1-22.

Kırkbir, Fazıl; Cançelik, Mehmet (2013), “Türkiye'de Siyaset Pazarlamasında Rakibe Pazarlama Üzerine Alan Araştırması: Trabzon İli Örneği", Gümüşhane Üniversitesi Sosyal Bilimler Elektronik Dergisi, No.8: 58-73.

Kim, Kwang-Jae; Jeong, In-Jun; Park, Jeong-Cheol; Park, Young-Jun; Kim, Chan-Gyu; Kim, Tae-Ho (2007), "The Impact of Network Service Performance on Customer Satisfaction and Loyalty", Expert Systems with Applications, Vol. 32, No. 3: 822-831.

Kolovas, Loannis; Harris, Phil (2005), "Political Marketing And Political Communication: The Relationship Revisited", http://eprints.otago.ac.nz/32/01/pm-pc.pdf, (Erişim: 10.04.2018)

Kotler, Philip; Levy, Sidney J. (1969), “Broadening the Concept of Marketing, Journal of Marketing, Vol. 33, No. 1: 1015.

Kushin, Matthew James; Yamamoto, Masahiro (2010), “Did Social Media Really Matter? College Students' Use of Online Media and Political Decision Making in the 2008 Election", Mass Communication and Society, Vol 13, No. 5: 608630.

Labrecque, Lauren L. (2014), "Fostering Consumer-Brand Relationships in Social Media Environments: The Role of Parasocial Interaction", Journal of Interactive Marketing, Vol. 28, No.2: 134-148.

Lees-Marshment, Jennifer (2001), "The Marriage of Politics and Marketing”, Political Studies, Vol. 49, No. 4: 692-713.

Lees-Marshment, Jennifer (2003), "Political Marketing: How to Reach that Pot of Gold”, Journal of Political Marketing, Vol. 2, No. 1: 1-32.

lees-Marshment, Jennifer (2009), “Political Marketing and The 2008 New Zealand Election: A Comparative Perspectivei", Australian Journal of Political Science, Vol. 44, No. 3: 457-475.

Lees-Marshment, Jennifer (2014), “Political Marketing Principles and Applications”, Second Edition, London.

Lilleker, Darren G.,; Pack, Marc; Jakson, Nigel (2010), "Political Parties and Web 2.0: The Liberal Democrat Perspective", Politics, Vol. 30, No. 2: 105-112.

Liñán, Fırancisco; Chen, Yi-Wen (2009), “Development and Cross-Cultural Application of a Specific Instrument to Measure Entrepreneurial Intentions", Entrepreneurship Theory and Practice, Vol. 33, No. 3: 593-617.

Litvin, Stephen V.; Goldsmith, Ronald E.; Pan, Bing (2008), "Electronic Word-of-Mouth in Hospitality and Tourism Management", Tourism Management, No.29: 458-468.

Lock, Andrew; Harris, Phil (1996), “Political marketing -Vive la Différence!”, European Journal of Marketing, Vol. 30, No. 10/11: 14-24.

Maryani, Dedeh (2015), "The Analysis Of Political Marketing Mix In Influencing Image And Reputation Of Political Party And Their Impact Toward The Competitiveness Of Political Party" (The Survey Of Voters In West Java Province), International Journal of Scientific \& Technology Research, Vol. 4, No. 11: 101-111.

McDonald, Malcolm H.B. (1989), "Marketing Planning and Expert Systems: An Epistemology of Practice”, Marketing Intelligence \& Planning, Vol.7, No.7/8: 16-23.

Mehrabi, Amir, Islami, Hossein; Aghajani, Mojtaba (2014), “The Effect of Social Media Marketing on Customers' Brand Loyalty", International Journal of Academic Research in Business and Social Sciences, Vol. 4, No. 8: 480-495. 
Mohamad, Nor C.S.; Muhammad, Hasmi A.H.; Karia, Noorliza (2009), “Political Marketing vs. Commercial Marketing: Something in Common for Gains", $6^{\text {th }}$ Global Conference on Business \& Economics, Gutman Conference Center, USA.

Moorman, Christine; Zaltman, Gerald; Deshpande, Rohit (1992), "Relationships Between Providers and Users of Market Research: The Dynamics of Trust Within and Between Organizations", Journal of Marketing Research, Vol. 29 No. 3: 314-328.

Morgan, Robert M.; Hunt, Shelby D. (1994), "The Commitment-Trust Theory of Relationship Marketing", Journal of Marketing, Vol.58, No. 3: 20-38.

Nevzat, Raziye; Amca, Yılmaz; Tanova, Cem; Amca, Hasan (2016), “Role of Social Media Community in Strengthening Trust and Loyalty for a University", Computers in Human Behavior, No. 65: 550-559.

Nguyen, Nha; Leclerc, Andre; Leblanc, Gaston (2013), "The Mediating Role of Customer Trust on Customer Loyalty", Journal of Service Science and Management, Vol. 6, No.1: 96-109.

O'Cass, Aron (1996), "Political Marketing and The Marketing Concept", European Journal of Marketing, Vol. 30, No. 10/11: 37-53.

Okumuş, Abdullah (2007), “Pazarlama Anlayışında Siyasal Pazarlamanın Yeri ve Pazar Konumlarına Göre Siyasi Partilerin Stratejik Analizi”, Dumlupınar Üniversitesi Sosyal Bilimler Enstitüsü Dergisi, S. 17: 157-172.

Oliver, Richard L. (1999), “Whence Consumer Loyalty?”, Journal of Marketing, No. 63: 33-44.

Ozturk, Resul; Coban, Suzan (2019), "Political Marketing, Word of Mouth Communication and Voter Behaviours Interaction", Business and Economics Research Journal, Vol. 10, No. 1: 245-258.

Papadopoulou, Panagiota; Andreou, Kanellis Panagiotis; Martakos, Drakoulis (2001), "Trust and Relationship Building in Electronic Commerce", Internet Research, Vol. 11, No. 4: 322-332.

Pettigrew, Andrew M. (1977), "Strategy Formulation as a Political Process", International Studies of Management \& Organization, Vol.7, No. 2: 78-87.

Polat, Cihat; Külter, Banu (2008), “Genç Seçmenler Gözüyle Siyasal Ürün (siyasi lider) Özellikleri: Ankara'daki Üniversite Öğrencileri Üzerine Bir Çalışma”, Insan Bilimleri Dergisi, C. 5 S. 1: 1-31.

Rachmat, Muhammad (2014), "The Impact of Political Brand Trust on Voting Intention: Evidence from 2013 North Maluku Governor Election”, IUP Journal of Brand Management, Vol.11, No. 2: 55-70.

Riezebos, Peter; De Vries, Sjoerd A.; Walter, De Vries Pieter; De Zeeuw, Erik (2011), "The Effects of Social Media on Political Party Perception and Voting Behavior", IADIS International e-Democracy, Equity and Social Justice, 1119.

Saleem, Anum; Ellahi, Abida (2017), "Influence of Electronic Word of Mouth on Purchase Intention of Fashion Products on Social Networking Websites", Pakistan Journal of Commerce and Social Sciences, Vol. 11, No. 2: 597-622.

Sarwar, Muhammad Zaman; Abbasi, Kashif Shafique; Pervaiz, Saleem (2012), "The Effect of Customer Trust on Customer Loyalty and Customer Retention: A Moderating Role of Cause Related Marketing", Global Journal of Management and Business Research, Vol. 12, No. 6: 26-36.

Scammell, Margaret (1999), "Political Marketing: Lessons for Political Science, Political Studies", Vol. 47, No. 4: 718739.

Schiffman, Leon; Thelen, Shawn T.; Sherman, Elaine (2010), "Interpersonal and Political Trust: Modeling Levels of Citizens' Trust”, European Journal of Marketing, Vol.44, No. 3/4: 369-381.

Schofield, Peter; Reeves, Peter (2015), "Does the Factor theory of Satisfaction Explain Political Voting Behaviour?", European Journal of Marketing, Vol. 49, No. 5/6: 968-992.

Shama, Avraham (1975), "An Analysis of Political Marketing", (Ed. Gerald Zaltman; Brian Sternthal), in SV - Broadening the Concept of Consumer Behavior, Association for Consumer Research, 106-116.

Sharma, Neeru; Patterson, Paul G. (2000), "Switching Costs, Alternative Attractiveness and Experience as Moderators of Relationship Commitment in Professional, Consumer Services", International Journal of Service Industry Management, Vol. 11, No. 5: 470-490.

Smith, Gareth; Hirst, Andy (2001), "Strategic Political Segmentation-a New Approach For a New Era of Political Marketing", European Journal of Marketing, Vol. 35, No. 9/10: 1058-1073.

Son, Jung-Eun; Kim, Hee-Woong; Jang, Yoon-Jung (2012), "Investigating Factors Affecting Electronic Word-OfMouth In The Open Market Context: A Mixed Methods Approach", Pacific Asia Conference on Information Systems (PACIS), $1-16$. 


\section{Eskişehir Osmangazi Üniversitesi iiBF Dergisi}

Srinivasan, Srini S.; Anderson, Rolph; Ponnavolu, Kishore (2002), “Customer Loyalty in ECommerce: An Exploration of Its Antecedents and Consequences", Journal of Retailing, Vol. 78, No. 1: 41-50.

Suhr, Diana (2006), "The Basics of Structural Equation Modeling", University of Northern Colorado, 1-19. file://C:/Users/hp/Downloads/TUT-Suhr.pdf (Erişim: 03.01.2018)

Takhire, Mohammad; Joorshari, M.R. Taghizadeh (2015), "Evaluatıon of Effectıve Factors on Customer Decision-Making Process in the Online Environment", International Journal of Managing Public Sector Information and Communication Technologies (IJMPICT), Vol. 6, No. 3: 1-11.

Tan, Ahmet; Baydaş, Abdulvahap (2017), “Seçmen Özelliklerinin Oy Verme Davranışı Üzerindeki Etkileri”, Iğdır Üniversitesi Sosyal Bilimler Dergisi, S. 13: 592-622.

Temple, Mick (2010), "Political Marketing, Party Behaviour and Political Science”, (Ed. Jennifer Lees-Marshment, Jesper Strömbäck, Chris Rudd), Global Political Marketing, Routledge Research in Political Communication, Abingdon, 263-277.

Thoumrungroje, Amonrat (2014), "The Influence of Social Media Intensity and EWOM on Conspicuous Consumption", Procedia - Social and Behavioral Sciences, No. 148: 7-15.

Tsai, Ming-Tien; Tsai, Chung-Lin; Chang, Han Chao (2010), "The Effect of Customer Value, Customer Satisfaction, and Switching Costs on Customer Loyalty: An Empirical Study of Hypermarkets in Taiwan", Social Behavior and Personality, Vol.38, No. 6: 729-740.

Usta, Resul; Memiş, Levent (2009), "Belediyelerde Hizmet Kalitesinin Seçmen Bağlılığı Üzerinde Etkisi”, Sosyal Bilimler Dergisi, S. 1: 213-235.

Valenzuela, Sebastian; Park, Namsu; Kee, Kerk F. (2009), "Is There Social Capital in a Social Network Site?: Facebook Use and College Students' Life Satisfaction, Trust, and Participation", Journal of Computer-Mediated Communication, No. 14: 875-901.

Visser, Max (1998), "Five Theories of Voting Action: Strategy and Structure of Psychological Explanation", https://pdfs.semanticscholar.org/, (Erişim: 02.01.2018)

Walsh, Gianfranco; Evanschitzky, Heiner; Wunderlich, Maren (2008), “Identification and Analysis of Moderator Variables:Investigating the Customer Satisfaction-Loyalty Link", European Journal of Mark., Vol.42, No. 9/10: 977-1004.

Widagdo, Suwignyo; Armanu; Noermijati; Rofiaty (2014), “Effect of Political Marketing Mix on Constituents Behavior in Selecting Candidates and Political Parties: Theoretical Studies in Legislative Elections", International Journal of Business and Management Invention, Vol. 3, No. 10: 47-54.

Wring, Dominic (1997), "Reconciling Marketing with Political Science: Theories of Political Marketing”, Journal of Marketing Management, Vol. 13, No. 7: 651-663.

Wu, Paul C.S.; Wang, Yun-Chen (2011), "The Influences of Electronic Word-of-Mouth Message Appeal and Message Source Credibility on Brand Attitude", Asia Pasific Journal of Marketing and Logistics, Vol. 23, No.4: 448-472.

Yang, Hongwei “Chris"; Dehart, Jean L. (2016), "Social Media Use and Online Political Participation Among College Students During the US Election 2012", Social Media + Society, 1-18. https://doi.org/10.1177/2056305115623802

Yıldırım, Mutlu (2014), “Parti Aday Tercihlerinin Seçmen Davranışına Etkisi 2009 Yerel Seçimleri Uşak ilii Örneği”, Pamukkale Üniversitesi Sosyal Bilimler Enstitüsü Dergisi, S. 17: 15-38.

Yıldız, Emel (2016), “Elektronik Ağızdan Ağıza İletişim: Tüketicilerin Elektronik Platformlarda Yorum Yazma Davranışını Etkileyen Faktörler", Gümüşhane Üniversitesi Sosyal Bilimler Enstitüsü Elektronik Dergisi (GÜSBEED), C. 7, S. 15: 156-175.

Yıldız, Salih; Çilingir, Zuhal (2010), “Elektronik Pazarlamada Müşteri Sadakatinin Geliştirilmesi: Karadeniz Teknik Üniversitesi Öğrencileri Üzerine Bir Araştırma”, Ç.Ü. Sosyal Bilimler Enstitüsü Dergisi, S. 1: 412-428.

Yılmaz, Veysel (2004), "Consumer Behaviour of Shopping Center Choice", Social Behavior and Personality, Vol. 32, No.8: 783-790.

Yılmaz, Veysel; Çelik, H. Eray; Ekiz, H. Erdoğan (2006), “Kuruma Bağlıı̆̆ı Etkileyen Faktörlerin Yapısal Eşitlik Modelleriyle Araştırılması: Özel ve Devlet Bankası Örneği”, Anadolu Üniversitesi Sosyal Bilimler Dergisi, Vol. 6, No. 2: 171-184. 


\section{Extended Summary}

\section{Proposal of a Structural Model about Social Media and Electronic Word of Mouth Communication in Political Mar- keting Process}

Marketing is an important activity that takes place in human life, updates itself in parallel with technological developments and becomes an integral part of modern society. The expansion of the marketing concept, especially the marketing of ideas, institutions and individuals, has brought political marketing methods and processes to the agenda. As political marketing has a place in today's life, competition has emerged intensively in the field of political marketing as in all other fields. In this context, it is possible to consider political marketing as a voter-oriented marketing process which aims to reach certain voting potential and provide voter confidence and loyalty by using traditional and modern marketing techniques in today's intense competition environment. It is seen that political candidates or parties whose main purpose is to win elections with the support of voters engage in political marketing activities and try to reach the masses by using the developing technology.

With political marketing, the target group is being persuaded to try to achieve a high voting rate. Social media is seen as an important actor in the marketing world especially when it is thought that technological developments are getting more and more new every day. Therefore social media, which is a means of promoting in the context of political marketing activities, is being used intensely. Nowadays, it can be said that word of mouth communication activities are carried to electronic media because people spend a lot of time in virtual environments. In this sense, it can be stated that the use of technological elements to communicate with voters in the political marketing process plays an important role in the success of political campaigns in the modern sense.

Voters can interact with other voters in electronic media through electronic word of mouth communication. Therefore, all this information exchange is also seen in voters who are consumers of political marketing. Voters can vote according to their own ideology and ideas, as well as interact with friends, family and relatives through social networks, which are electronic environments. For this reason, it is considered that the effective use of digital marketing methods and social media within the framework of modern marketing approach is very important in terms of reaching the voters and influencing the election results.

Purpose of this study is to determine the effects of social media factor on voter trust and loyalty with voter trust and loyalty on electronic word of mouth communication and voter behavior. It is seen in the literature that there are studies about the effects of political marketing social media factor on voter trust, voter loyalty and voter behavior. However, there are no studies in which political marketing, social media and electronic word of mouth communication are evaluated together. Therefore, the integration of these three conceptual structures reveals the importance and originality of the study. In this context, the research model has been developed by developing the model they have added to the literature with the studies of Kushin and Yamamoto (2010), Yang and DeHart (2016) and Dabula (2017). At the same time, electronic word of mouth communication factor was included in the model by making necessary literature studies.

Although the number of samples required for the study was determined as 384, in order to reduce the margin of error in the study, the number of sample mass was determined as 552. Some of the questionnaires were eliminated due to inaccuracy and 540 questionnaires were included in the research analysis. As a result, in this study, online survey was applied to 540 social media users with easy sampling method which is one of the non-random sampling methods. The data were analyzed in statistical package programs, the hypotheses were tested with structural equation model. It is considered that the results cannot be generalized to the main mass due to the use of non-random sampling method, but it can provide information about the main mass in part.

As a result of the study, it was concluded that political marketing social media factor had a direct effect on voter trust, direct and indirect effect on voter loyalty, and voter trust had a direct effect on voter loyalty. As a result of the research, it has been found that voter loyalty has a direct effect on electronic word of mouth communication, voter trust has a direct and indirect effect on voter behavior and voter loyalty has a direct and indirect effect on voter behavior. It was concluded that political marketing social media factor had direct and indirect effects on electronic word of mouth communication, indirectly on voter behavior, and electronic word of mouth communication had a direct effect on voter behavior.

According to the above-mentioned results, it can be said that the social media users trust the social media users from the social networking sites made by the political parties or leaders, and that this trust directly and indirectly affects their loyalty. It can be said that loyalty, which plays a vital role in consumer behavior, has an impact on the electronic word of mouth communication on social networking sites and all these factors may change the behavior of voters. In this sense, it is possible to say that political candidates or parties should use social media effectively as a strategic 


\section{Eskişehir Osmangazi Üniversitesi iiBF Dergisi}

marketing tool in order to encourage their candidates or parties, position them positively in the market and gain the support of voters while using social media platforms for marketing communication.

Findings obtained as a result of the analysis and interpretations made according to these findings are considered to be very important both in practice and theoretically. Considering the scope and limitations of this research, future research may be conducted with a large sample and may provide more general results. This research covers the most commonly used social networking sites Facebook, Twitter and Instagram users. For this reason, it is recommended that future studies be expanded to cover different social media platforms. 